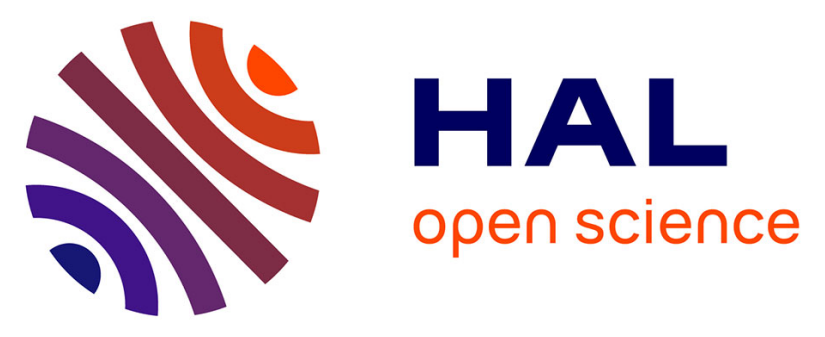

\title{
Comprehensive physicochemical study of dioctahedral palygorskite-rich clay from Marrakech High Atlas (Morocco)
}

Benaissa Rhouta, Ezzouhra Zatile, Lahcen Bouna, Omar Lakbita, Francis Maury, Lahcen Daoudi, Marie Christine Lafont, M'barek Amjoud, François Senocq, Amane Jada, et al.

\section{To cite this version:}

Benaissa Rhouta, Ezzouhra Zatile, Lahcen Bouna, Omar Lakbita, Francis Maury, et al.. Comprehensive physicochemical study of dioctahedral palygorskite-rich clay from Marrakech High Atlas (Morocco). Physics and Chemistry of Minerals, 2013, vol. 40 ( $\mathrm{n}^{\circ}$ 5), pp. 411-424. 10.1007/s00269-0130579-3 . hal-01172017

\section{HAL Id: hal-01172017 https://hal.science/hal-01172017}

Submitted on 6 Jul 2015

HAL is a multi-disciplinary open access archive for the deposit and dissemination of scientific research documents, whether they are published or not. The documents may come from teaching and research institutions in France or abroad, or from public or private research centers.
L'archive ouverte pluridisciplinaire HAL, est destinée au dépôt et à la diffusion de documents scientifiques de niveau recherche, publiés ou non, émanant des établissements d'enseignement et de recherche français ou étrangers, des laboratoires publics ou privés. 


\section{Open Archive TOULOUSE Archive Ouverte (OATAO)}

OATAO is an open access repository that collects the work of Toulouse researchers and makes it freely available over the web where possible.

This is an author-deposited version published in : http://oatao.univ-toulouse.fr/ Eprints ID : 14095

To link to this article : DOI:10.1007/s00269-013-0579-3

URL : http://dx.doi.org/10.1007/s00269-013-0579-3

To cite this version : Rhouta, Benaissa and Zatile, Ezzouhra and Bouna, Lahcen and Lakbita, Omar and Maury, Francis and Daoudi, Lahcen and Lafont, Marie Christine and Amjoud, M'Barek and Senocq, François and Jada, Amane and Aït Aghzzaf, Ahmed Comprehensive physicochemical study of dioctahedral palygorskiterich clay from Marrakech High Atlas (Morocco). (2013) Physics and Chemistry of Minerals, vol. 40 ( $\mathrm{n}^{\circ}$ 5). pp. 411-424. ISSN 0342-1791

Any correspondance concerning this service should be sent to the repository administrator: staff-oatao@,listes-diff.inp-toulouse.fr 


\title{
Comprehensive physicochemical study of dioctahedral palygorskite-rich clay from Marrakech High Atlas (Morocco)
}

\author{
Benaissa Rhouta $\cdot$ Ezzouhra Zatile $\cdot$ Lahcen Bouna $\cdot$ Omar Lakbita $\cdot$ \\ Francis Maury • Lahcen Daoudi - Marie Christine Lafont • M'Barek Amjoud • \\ François Senocq $\cdot$ Amane Jada $\cdot$ Ahmed Aït Aghzzaf
}

\begin{abstract}
This study is devoted to the physicochemical and mineralogical characterizations of palygorskite from Marrakech High Atlas, Morocco. The raw clay and its $\mathrm{Na}^{+}$-saturated $<2 \mu \mathrm{m}$ fraction were characterized using chemical, structural, and thermal analytical techniques. Measurements of specific surface area and porous volume are reported. The clay fraction was found to be made up of $95 \%$ of palygorskite and $5 \%$ of sepiolite. An original feature of this palygorskite is its deficiency in zeolitic $\mathrm{H}_{2} \mathrm{O}$. The half-cell structural formula of its dehydrated form was determined on the basis of 21 oxygens to be $\left(\mathrm{Si}_{7.92} \mathrm{Al}_{0.08}\right)\left(\mathrm{Mg}_{2.15} \mathrm{Al}_{1.4} \mathrm{Fe}_{0.4} \mathrm{Ti}_{0.05} \square_{1}\right)\left(\mathrm{Ca}_{0.03}\right.$ $\left.\mathrm{Na}_{0.08} \mathrm{~K}_{0.04}\right) \mathrm{O}_{21}$, while the hydrated form could be formulated as $\left(\mathrm{Si}_{7.97} \mathrm{Al}_{0.03}\right)\left(\mathrm{Mg}_{2.17} \mathrm{Al}_{1.46} \mathrm{Fe}_{0.40} \mathrm{Ti}_{0.05}\right)\left(\mathrm{Ca}_{0.03} \mathrm{Na}_{0.07} \mathrm{~K}_{0,03}\right)$ $\mathrm{O}_{20.18}(\mathrm{OH})_{1.94}\left(\mathrm{OH}_{2}\right)_{3.88} \cdot 2.43 \mathrm{H}_{2} \mathrm{O}$. These formulas show that the $\left(\mathrm{Al}^{3+}+\mathrm{Fe}^{3+}\right) / \mathrm{Mg}^{2+}$ ratio is around 0.84 , revealing a
\end{abstract}

B. Rhouta $(\bowtie) \cdot$ E. Zatile · L. Bouna - O. Lakbita ·

M. Amjoud - A. Aït Aghzzaf

Laboratoire de Matière Condensée et Nanostructures (LMCN), Faculté des Sciences et Techniques Guéliz,

Université Cadi Ayyad, BP 549,

Marrakech, Morocco

e-mail: b.rhouta@uca.ma

F. Maury $\cdot$ M. C. Lafont $\cdot$ F. Senocq

CIRIMAT, CNRS-UPS-INP, ENSIACET,

4 allée Emile Monso, BP 44362, 31030 Toulouse Cedex 4,

France

L. Daoudi

Laboratoire de Géosciences et Géoenvironnement,

Faculté des Sciences et Techniques Guéliz,

Université Cadi Ayyad, BP 549, Marrakech, Morocco

A. Jada

Institut de Sciences des Matériaux de Mulhouse IS2 M LRC

7228, CNRS, 15 rue jean Starcky BP 2488,

68057 Mulhouse Cedex, France pronounced dioctahedral character. Further, inside its octahedral sheet, it was determined that the inner $\mathrm{M}_{1}$ sites are occupied by vacancies, whereas the $\mathrm{M}_{2}$ sites are shared between $90 \%$ of trivalent cations $\left(78 \%\right.$ for $\mathrm{Al}^{3+}$ and $22 \%$ for $\mathrm{Fe}^{3+}$ ), $7.5 \%$ of $\mathrm{Mg}^{2+}$, and $2.5 \%$ of $\mathrm{Ti}^{4+}$, all of them linked to 1.94 of structural hydroxyls. The two remaining $\mathrm{Mg}^{2+}$ by half-cell occupy edge $\mathrm{M}_{3}$ sites and are coordinated to 3.88 molecules of $\mathrm{OH}_{2}$. Channels of this palygorskite are deficient in zeolitic $\mathrm{H}_{2} \mathrm{O}$ since they contain only $2.43 \mathrm{H}_{2} \mathrm{O}$ molecules. A correlation was found between these results and the observation of very intense and well-resolved FTIR bands arising from dioctahedral domains (mainly $\mathrm{Al}_{2} \mathrm{OH}, \mathrm{Fe}_{2} \mathrm{OH}$, and $\mathrm{AlFeOH}$ ) along with very small responses from a trioctahedral domain $\left(\mathrm{Mg}_{3} \mathrm{OH}\right)$. Accordingly, a schematic representation of the composition of the octahedral sheet was proposed. The cation exchange capacity, specific surface area, and total pore volume were also assessed to be ca. $21.2 \mathrm{meq} / 100 \mathrm{~g}, 116 \mathrm{~m}^{2} / \mathrm{g}$, and $0.458 \mathrm{~cm}^{3} / \mathrm{g}$, respectively.

Keywords Palygorskite - Marrakech High Atlas . Characterizations · Fibrous clay · Dioctahedral ·

Trioctahedral

\section{Introduction}

Palygorskite, also called attapulgite, is an interesting fibrous hydrated aluminum magnesium silicate mineral with versatile industrial applications (Murray 2000). From historical and cultural viewpoints, palygorskite was known by ancient civilizations since it was used during Pre-Colombian Mesoamerican period to manufacture the prominent and mysterious hybrid pigment, called Maya Blue, which is a combination of palygorskite, indigo dye, and metallic particles (Van Olphen 1966; Yacamán et al. 1996; 
Polette-Niewold et al. 2007). Most recently, increasing interest was devoted to fibrous clay minerals due to their adsorptive capacity and their ability to be combined to organic or inorganic compounds, leading to the design of versatile nanostructured functional materials (Zhao et al. 2006; Bouna et al. 2011; Su et al. 2012; Liu et al. 2012; Li et al. 2012). In comparison with other clay minerals, palygorskite is a fuller's earth exhibiting specific desirable sorptive, colloidal-rheological, and catalytic properties (Galán et al. 1994; Galán 1996; Wang et al. 2012). Technological applications of palygorskite were shown by Galán (1996) to be due to its physicochemical properties, mainly composition, surface area, porosity, among others, and especially fibrous structure.

In this context, the structure of palygorskite was described by Bradley's model (Bradley 1940; Bailey 1980). It consists of continuous sheets of tetrahedrons $(\mathrm{T})$ in which the apical oxygens are alternatively inverted pointing in opposite directions and binding to a discontinuous octahedral sheet (O), which forms ribbons elongated in the direction of the c-axis (Krekeler and Guggenheim 2008; Fig. 1a, b). In this clay mineral, the TOT ribbons have an average width along the $b$-axis of two linked tetrahedral chains. Besides, they are disposed according to a chessboard-like arrangement when observed on the (001) plane, linked one another via $\mathrm{Si}-\mathrm{O}-\mathrm{Si}$ bridges. The octahedral ribbon is made up of five sites whose the inner one is $\mathrm{M}_{1}$, the two following ones $\left(\mathrm{M}_{2}\right)$ are coordinated to two hydroxyls, and the last two located on edges are $\mathrm{M}_{3}$ (Fig. 1c). The linked ribbons thus form a continuous 2:1 layer along the $c$-axis (Fig. 1a, c) with a limited extent along the $b$-axis (Fig. 1b). Rectangular channels of about $3.7 \times 6.0 \AA^{2}$ wide (Huang et al. 2007) are present. They lie between the blocks of opposing 2:1 ribbons and extend parallel to the fiber direction. As a result of the discontinuity of the silica sheets, silanol groups $(\mathrm{Si}-\mathrm{OH})$ are present at the external surfaces of the particles located at the edges of the channels (Fig. 1) (Shariatmadari 1998; Ruiz-Hitzky 2001). Further, the clay mineral contains two kinds of water molecules, ones coordinated to the octahedral cations and the other weakly bonded in the channels, namely the zeolitic $\mathrm{H}_{2} \mathrm{O}$. These channels may also contain exchangeable cations.

Isomorphous substitutions principally of $\mathrm{Al}$ and $\mathrm{Fe}$ for $\mathrm{Mg}$ occur in the octahedral sites of this silicate. Thus, a small number of exchangeable compensating $\mathrm{Na}^{+}, \mathrm{K}^{+}$, $\mathrm{Ca}^{2+}$, and $\mathrm{Mg}^{2+}$ cations (Garcia-Romero et al. 2007), zeolitic $\mathrm{H}_{2} \mathrm{O}$, and four structural $\mathrm{OH}_{2}$ molecules per formula unit bonded to $\mathrm{M}_{3}$ edge sites are contained in the channels (Mifsud et al. 1978; Suárez and García-Romero 2006). Palygorskite has a general theoretical formula

$\left(\mathrm{Mg}_{5-\mathrm{y}-\mathrm{z}} \mathrm{R}^{3+}{ }_{y} \square_{z}\right)\left(\mathrm{Si}_{8-\mathrm{x}} \mathrm{R}_{\mathrm{x}}^{3+}\right) \mathrm{O}_{20}(\mathrm{OH})_{2}\left(\mathrm{OH}_{2}\right)_{4} \mathrm{R}_{(\mathrm{x}-\mathrm{y}+2 \mathrm{z}) / 2}^{2+}$ $\left(\mathrm{H}_{2} \mathrm{O}\right)_{4}$, where $\square$ is a vacant site and $\mathrm{R}$ represents $\mathrm{Al}$ or $\mathrm{Fe}$, depending on the origin and deposition conditions (Huang et al. 2007). So, a variable dioctahedral-trioctahedral character can be assigned to palygorskite (Galán and Carretero 1999; Chahi et al. 2002). The dioctahedral end-member at $y=2$ and $z=1$ is characterized by the formula $\left(\mathrm{Mg}_{2} \mathrm{R}^{3+}{ }_{2} \square_{1}\right)\left(\mathrm{Si}_{8-\mathrm{x}} \mathrm{R}_{\mathrm{x}}^{3+}\right) \mathrm{O}_{20}(\mathrm{OH})_{2}\left(\mathrm{OH}_{2}\right)_{4} \mathrm{R}_{\mathrm{x} / 2}^{2+}\left(\mathrm{H}_{2} \mathrm{O}\right)_{4}$ showing that only four of five octahedral positions available are filled with $\mathrm{R}^{3+}$ occupying the $\mathrm{M}_{2}$ sites and $\mathrm{Mg}^{2+}$ occupying the $M_{3}$ while $M_{1}$ is vacant (Güven et al. 1992). On the other hand, the trioctahedral end-member palygorskite at $y=0$ and $z=0$ can be represented by the formula $\left(\mathrm{Mg}_{5}\right)\left(\mathrm{Si}_{8-\mathrm{x}} \mathrm{R}_{\mathrm{x}}^{3+}\right) \mathrm{O}_{20}(\mathrm{OH})_{2}\left(\mathrm{OH}_{2}\right)_{4} \mathrm{R}_{\mathrm{x} / 2}^{2+}\left(\mathrm{H}_{2} \mathrm{O}\right)_{4}$ for which all the five octahedral positions are filled with $\mathrm{Mg}^{2+}$.

The occurrence of palygorskite in Marrakech High Atlas was reported by several authors (Daoudi and Deconninck 1994; Ben Aboud et al. 1996; Daoudi 2004). These studies were mainly focused on the knowledge of their genesis and/or their particular geological features. Likewise, we recently demonstrated the possibility of immobilization of $\mathrm{TiO}_{2}$ nanoparticles $(\sim 8 \mathrm{~nm})$ on fibers of this palygorskite to produce nanocomposite materials as original supported photocatalysts. Indeed, they exhibited remarkable photocatalytic activity in the removal from aqueous medium of Orange $\mathrm{G}$ dye widely used in textile industry (Bouna et al. 2011).

Despite all these studies, a thorough characterization of palygorskite from Marrakech High Atlas is still incomplete. Pursuing a general program of research on the characterization, properties, and technological development of natural clays from Morocco (Rhouta et al. 2008; Bouna et al. 2011, 2012; Ait Aghzzaf et al. 2012), this study aims at a detailed analysis of the raw clay from Marrakech High Atlas and its $<2 \mu \mathrm{m}$ fraction in order to determine their mineralogical, physicochemical, textural, and structural properties, especially by elucidating the composition of its octahedral sheets. Knowledge of these properties is vital for further considering the clay for use as a cheap abundant natural starting material in the development of innovative clay-based materials.

\section{Geological setting}

The Uppermost Cretaceous-Paleogene sediments of the Marrakech High Atlas consist chiefly of alternations of marl, carbonate, gypsum, and phosphatic bed suggesting a shallow sea environmental deposit (Marzoqi 1990). Sedimentary facies and clay assemblages' evolution of this series is studied in the Asni region, $45 \mathrm{~km}$ South of Marrakech, where they constitute thick accumulations exceeding $400 \mathrm{~m}$. The sedimentary sequences are organized in two systems which are separated by a regionalscale discontinuity (Fig. 2):

(i) The lower sedimentary system which is probably of Maastrichtian age (Chellai et al. 1995), comprise elementary sequences composed by alternations of 
Fig. 1 Schematic representations of palygorskite structure: a overview of the fibrous morphology, the presence of channels, and the formation of discontinuous ribbons; b projection on (001) plane; and c projection on (100) plane showing an octahedral ribbon with the $\mathrm{M}_{1}, \mathrm{M}_{2}$, and $\mathrm{M}_{3}$ sites as well as structural hydroxyls, coordinated and zeolitic $\mathrm{H}_{2} \mathrm{O}$ [Suárez and García-Romero (2006)] (a)

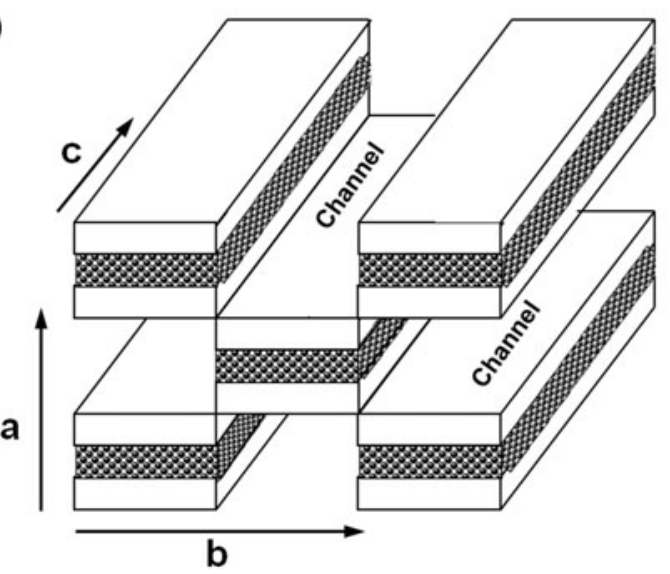

(b)

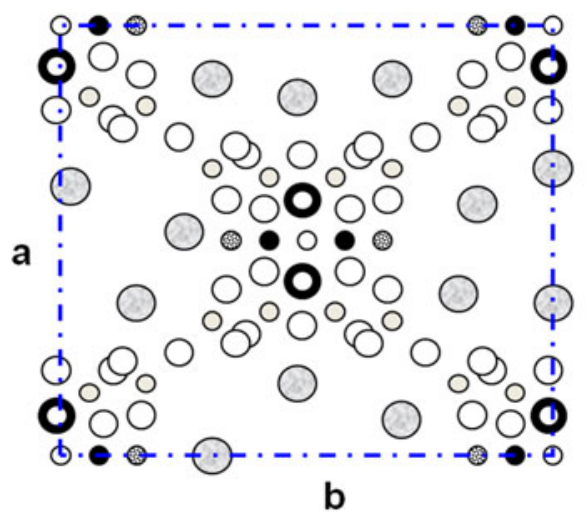

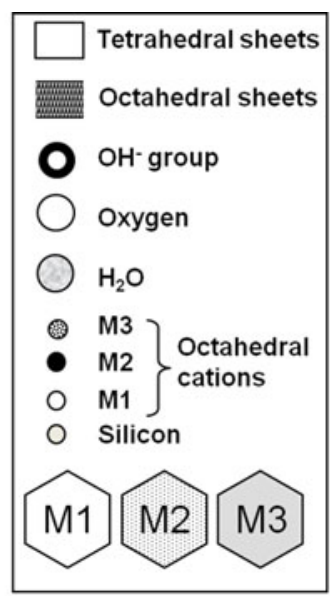

(c)

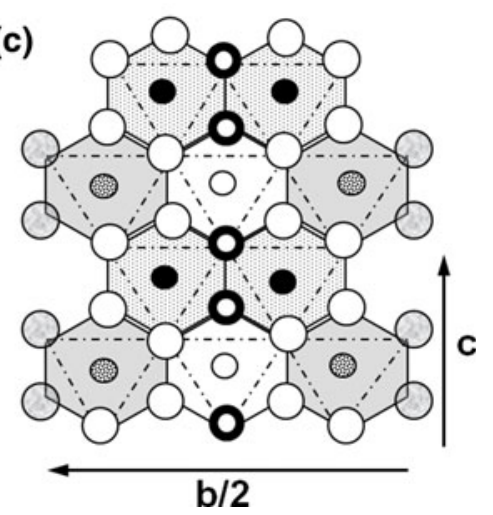

gypsum, occurring as bands and veins, and banks of bioclastic carbonates which became increasingly diversified upwards. The clay fraction is mainly composed of smectite, illite, and little amount of palygorskite (from Pk0 to Pk1 levels).

(ii) The upper sedimentary system is of Paleocene to Lutetian age (Chellai et al. 1995). The lower member is composed of yellow heterogeneous marls followed by dolomitic bars and phosphate deposits. The associated clay fraction is composed essentially by fibrous clay (palygorskite and sepiolite) quite in the same proportions (Pk2, Pk3). The upper member consists of a thick series of marls intercalated by thin dolomitic or calcarenite bars. This unit is characterized by the widespread occurrence of palygorskite, which reaches its maximum at the top of the series ( $\mathrm{Pk} 7)$. Thus, this mineralogical and physicochemical study is focused on this PK7 palygorskite-rich unit.

\section{Experimental}

Purification

Raw clay samples (designated PK7 where PK stands for "Plateau Kik") were first crushed and sieved to $50 \mu \mathrm{m}$ and treated with $\mathrm{HCl}$ solution $(0.2 \mathrm{~N})$. The almost pure $\mathrm{Na}^{+}$homoionic clay fraction (labeled $\mathrm{Na}^{+}$-PK7) was recovered by the procedure described elsewhere (Rhouta et al. 2008). For removing poorly crystalline iron-rich impurities, which could be present as iron oxides and/or iron hydroxide gel (Goodman et al. 1976), the $\mathrm{Na}^{+}$-exchanged $<2 \mu \mathrm{m}$ fraction $\left(\mathrm{Na}^{+}-\mathrm{TAG}\right)$ was treated with a dithionide-citrate solution buffered with sodium bicarbonate according to the procedure reported by Mehra and Jackson (1956). For this purpose, $1 \mathrm{~g}$ of $<2 \mu \mathrm{m}$ fraction powder was dispersed under stirring at $80^{\circ} \mathrm{C}$ in an aqueous solution of $40 \mathrm{~mL}$ of sodium citrate $(0.3 \mathrm{~mol} / \mathrm{L})$ and $5 \mathrm{~mL}$ of sodium bicarbonate $(1 \mathrm{~mol} / \mathrm{L})$. Thereafter, $500 \mathrm{mg}$ of sodium dithionide was added to this dispersion which was further kept at $80{ }^{\circ} \mathrm{C}$ under stirring for additional $15 \mathrm{~min}$. Finally, the clay material was recovered by centrifugation at $\times 604$ for $10 \mathrm{~min}$ and washed several times to remove excess of reacting compounds.

\section{Characterizations}

Microstructural observations and qualitative compositions were performed on raw clay and its $\mathrm{Na}^{+}$-exchanged $<2 \mu \mathrm{m}$ fraction with a Jeol JSM 6400 scanning electron microscope (SEM) and a Jeol JEM 2010 transmission electron microscope (TEM) equipped with an energy-dispersive 


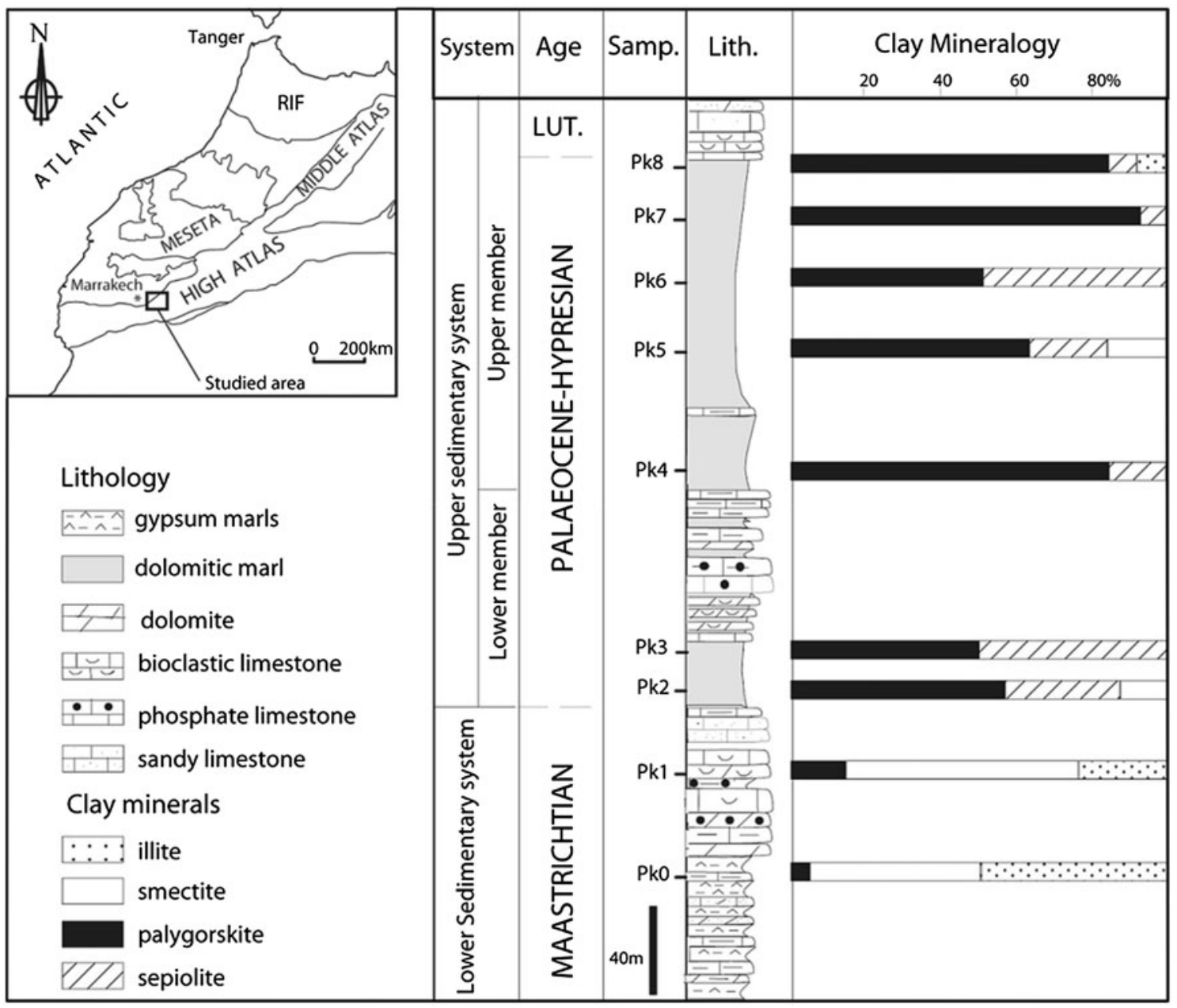

Fig. 2 Geographical location of the sampling area (top left corner). Lithology and clay mineralogy of the Asni section

X-ray Tracor analyzer (EDS). SEM observations were performed by spreading and fixing the powder sample on double-sided adhesive and conductive tape stuck on the sample holder. To ensure a good electron conduction, the prepared samples were coated by cathodic sputtering with a thin silver film (a few nanometers of thickness) using an Edwards S150B metalizer prior to be introduced in the microscope. For TEM examinations, a small amount of material powder was first dispersed in ethanol with an ultrasonic bath. After that, droplets of this dispersion were placed on a copper grid ( $3 \mathrm{~mm}$ in diameter) covered by a thin layer of amorphous carbon. After evaporation of ethanol, particles of the sample were retained on the grid and it was introduced in the TEM apparatus using a sample holder.

$\mathrm{X}$-ray diffraction $(\mathrm{XRD})$ patterns were recorded for raw clay (PK7) and $<2 \mu \mathrm{m} \mathrm{Na}{ }^{+}$-saturated fraction $\left(\mathrm{Na}^{+}\right.$-PK7) on oriented flat plates over the $2 \theta$ angular range $2-60^{\circ}$. A Seifert XRD 3000TT apparatus equipped with a diffracted beam graphite monochromator was used in the Bragg-Brentano configuration $\left(\mathrm{Cu} \mathrm{K}_{\alpha(1+2)}\right.$ radiation). The thermogravimetric (TG) and differential thermal analysis (DTA) thermograms were collected using a Setaram Labsys apparatus using sample masses of ca. $60 \mathrm{mg}$ and a temperature ramp of $10 \mathrm{~K} / \mathrm{min}$ from ambient to $1,273 \mathrm{~K}$. Solid-state ${ }^{27} \mathrm{Al}$ and ${ }^{29} \mathrm{Si}$ magic angle spinning nuclear magnetic resonance (MAS-NMR) spectra were collected at room temperature with a Bruker Advance 500 spectrometer equipped with a 4-mm cross-polarization magic angle spinning probe fitted with a standard spinning assembly. ${ }^{27} \mathrm{Al}$ MAS-NMR spectra were obtained at $130.32 \mathrm{MHz}$, while ${ }^{29} \mathrm{Si}$ MAS-NMR spectra were recorded at $99.36 \mathrm{MHz} .{ }^{27} \mathrm{Al}$ chemical shifts were recorded with respect to $\left[\mathrm{Al}\left(\mathrm{H}_{2} \mathrm{O}\right)_{6}\right]^{3+}$ as an external reference, and ${ }^{29} \mathrm{Si}$ chemical shifts were referred to tetramethylsilane (TMS).

The chemical compositions of crude clay and its $<2 \mu \mathrm{m}$ $\mathrm{Na}^{+}$-saturated fraction were determined by inductively coupled plasma (ICP) by mean of a Thermo Electron Series $\mathrm{X} 2$ spectrometer equipped with a Meinhard nebulizer and a SimulScan FTE-type detector. The clay samples were heated to $800{ }^{\circ} \mathrm{C}$ overnight prior to analysis to dehydrate the samples (Caillere et al. 1982; Rautureau et al. 2004). 
Mid-infrared (MIR) spectroscopic studies were undertaken using a Nicolet 5700 spectrometer under ambient conditions in the frequency range $400-4,000 \mathrm{~cm}^{-1}$ using $\mathrm{KBr}$ pellets. The pellets contained a mixture of $2 \mathrm{mg}$ of clay material with $198 \mathrm{mg}$ of $\mathrm{KBr}(\sim 1 \mathrm{wt} \%)$. The near-infrared (NIR) spectra were obtained using a Perkin Elmer Lambda 19 spectrophotometer equipped with an integrating sphere coated by $\mathrm{BaSO}_{4}$, which was used as a reference. The spectra were recorded with samples deposited on quartz plates from 4,000 to $8,000 \mathrm{~cm}^{-1}$ at a resolution of $5 \mathrm{~cm}^{-1}$.

The cation exchange capacity (CEC) of the raw clay (PK7) and its purified $\mathrm{Na}^{+}$-exchanged fraction $\left(\mathrm{Na}^{+}-\mathrm{PK} 7\right)$ was determined according to the method based on adsorption of hexamine cobalt complex (Mantin and Glaeser 1960). To improve clay minerals particles to be sufficiently wetted by the adsorbate, material dispersion was stirred under ultrasounds to disaggregate clay mineral fibers. The specific surface area was measured from the adsorption-desorption isotherms of $\mathrm{N}_{2}$ at $77 \mathrm{~K}$ using an ASAP 2020 V 3.01 H adsorption analyzer from Micromeritics. Prior to $\mathrm{N}_{2}$ adsorption-desorption measurements, samples weighting $0.162 \mathrm{~g}$ were outgassed either at $150{ }^{\circ} \mathrm{C}$ overnight or for $24 \mathrm{~h}$ or at $140{ }^{\circ} \mathrm{C}$ for $9 \mathrm{~h}$ till the pressure reached around $10^{-2}$ Torr. The specific surface area was determined by the Brunauer-Emmett-Teller (BET) method (Brunauer et al. 1938).

\section{Results and discussion}

\section{Microstructural analysis (TEM-SEM-EDS)}

TEM micrograph obtained from raw clay shows microfibers mixed with rhomboidal crystals characteristic of carbonates (Fig. 3a). Punctual EDS analysis performed on selected area of several fibers or along a same fiber (spectra not reported) revealed that these fibers are aluminum magnesium silicate with noticeable amount of iron.

The overview of $\mathrm{Na}^{+}$-exchanged fine fraction afforded by SEM imaging (Fig. 3b) shows fibers bundles free from carbonate impurities. The fibers appear either as wellseparated individual fibers or as assemblages of several fibers having an average length of ca. $1 \mu \mathrm{m}$ and a diameter ranging from 10 to $50 \mathrm{~nm}$. Besides, these micrographs exhibit various sizes of interfibers pores, widely ranging from $10 \mathrm{~nm}$ to $1 \mu \mathrm{m}$, indicating the occurrence of especially mesopores $(2 \mathrm{~nm}<$ size $<50 \mathrm{~nm})$ and macropores (size $>50 \mathrm{~nm}$ ) (Rouquerol et al. 2003). But, this does not exclude the presence of interfibers micropores (size $<2 \mathrm{~nm}$ ) (Rouquerol et al. 2003, Cases et al. 1991) which could not be identified due to magnitude limitation of the TEM apparatus used herein.
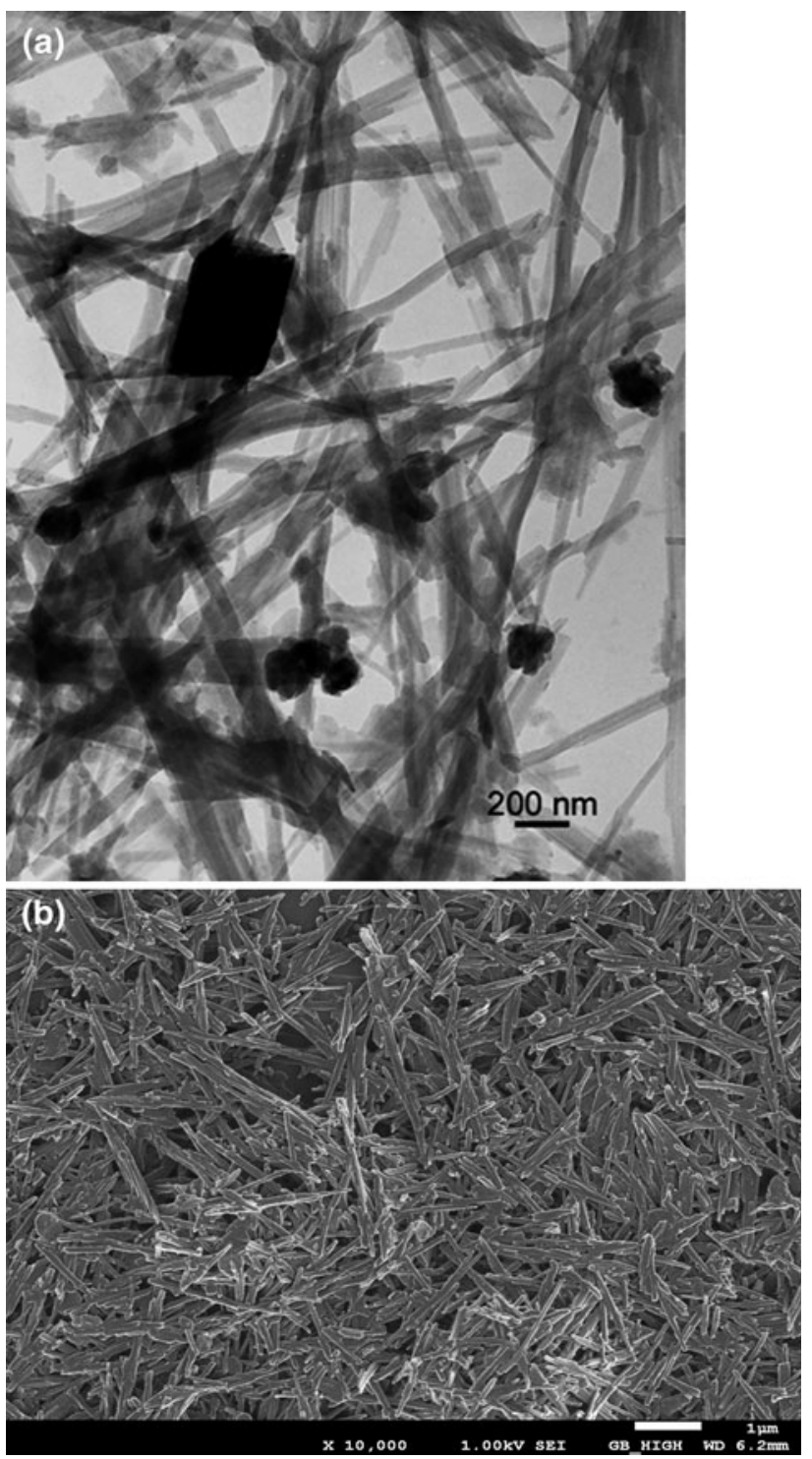

Fig. 3 a TEM micrograph of raw clay (PK7) showing clay mineral fibers mixed with rhombohedral crystals of carbonates. b SEM micrograph of $\mathrm{Na}^{+}$exchanged purified fine fraction $\left(\mathrm{Na}^{+}-\mathrm{PK} 7\right)$

Crystallographic structure and phase identification (XRD)

The XRD patterns of raw clay sample PK7 (Fig. 4a) show the reflections of a fibrous clay mineral $(\mathrm{P})$ along with those corresponding to quartz (JCPDS file: 03-065-0466) and to two kinds of carbonates: calcite (C) $\mathrm{Mg}_{0.03} \mathrm{Ca}_{0.97} \mathrm{CO}_{3}$ (JCPDS file: 01-089-1304) and ankerite (A) $\mathrm{Ca}_{1.01} \mathrm{Mg}_{0.45}$ $\mathrm{Fe}_{0.54}\left(\mathrm{CO}_{3}\right)_{2}$ (JCPDS file: 01-084-2066) in good agreement with TEM-EDS analyses. Upon purification, carbonates peaks disappear, whereas those of quartz are still present indicating the success of the removal of carbonate while minor amount of quartz remains in the sample (estimated to only a few percent from the relative XRD intensity). At the 

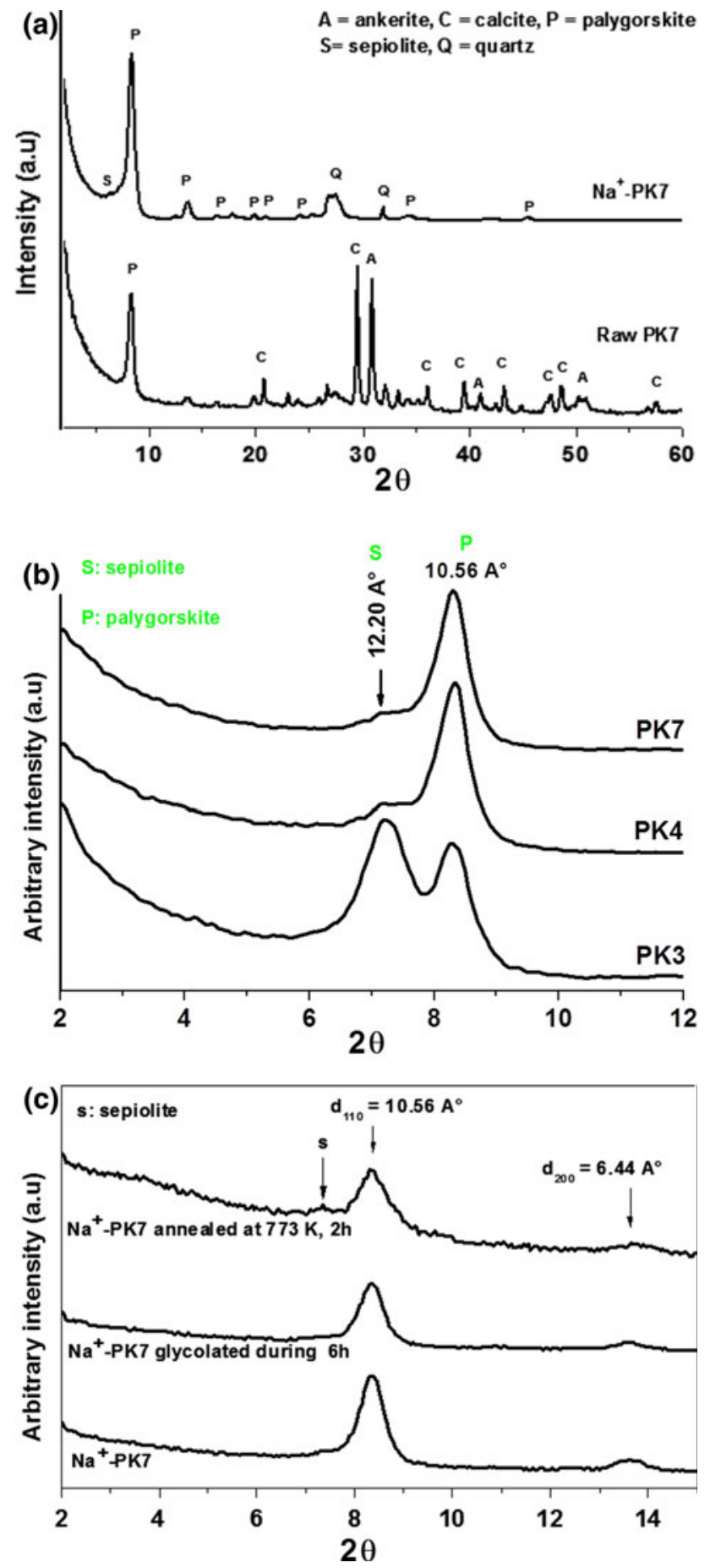

Fig. 4 XRD patterns of the raw clay (PK7) and its isolated fine fraction $\left(\mathrm{Na}^{+}-\mathrm{PK} 7\right)$ : a before (PK7) and after purification $\left(\mathrm{Na}^{+}-\mathrm{PK} 7\right)$; b Comparison of XRD patterns of samples picked up from different units (PK3, PK4, and PK7); $\mathbf{c}$ XRD patterns in the small angle region of fine clay fraction $\left(\mathrm{Na}^{+}\right.$-PK7) before and after successive different treatments. Reproduced with permission from Bouna et al. (2011)

same time, reflections of fibrous clay mineral appear more resolved and intensified. Their angular positions are quite similar to those reported for palygorskite from other occurrences (Christ et al. 1969; Chisholm 1990, 1992; Artioli and Galli 1994; Fernández et al. 1999). The $\mathrm{d}_{110}$ reflection found around $10.56 \AA\left(2 \theta \approx 8.36^{\circ}\right)$ confirms that it corresponds to palygorskite. Sepiolite coexists with palygorskite in the PK7 clay but in a minor amount as evidenced by the detection of a small shoulder at around $12.2 \AA\left(2 \theta \approx 7.25^{\circ}\right)$ corresponding to its (110) peak (Fig. 4a). The intensity of this additional peak is found to increase for the samples taken from deeper units (PK3 and PK4) as evidenced by XRD (Fig. 4b). Semiquantitative estimations, based on "peak height ratios" (Thorez 1976; Holtzapffel 1985; Pevear and Mumpton 1989; Galhano et al. 1999) of $\mathrm{d}_{110}$ reflections of palygorskite and sepiolite, deduced from X-ray diagram of $\mathrm{Na}^{+}$-PK7 sample (Fig. 4a, b), indicate that the fibrous clay mineral fraction is a mixture of $95 \%$ of palygorskite and $5 \%$ of sepiolite in good agreement with geological context described above. The diffractograms obtained from oriented flat plates of the purified $\mathrm{Na}^{+}$-exchanged fine $(<2 \mu \mathrm{m})$ fraction $\left(\mathrm{Na}^{+}-\mathrm{PK} 7\right)$, after being either glycolated for $6 \mathrm{~h}$ or heat treated at $500{ }^{\circ} \mathrm{C}$ for $2 \mathrm{~h}$ (Fig. $4 \mathrm{c}$ ), show that the $\mathrm{d}_{110}$ reflection at $10.56 \AA$ is not affected by ethylene glycol solvation or the heat treatment. This confirms that the palygorskite investigated herein is not associated to any swellable smectite in contrast to palygorskite from phosphorite deposits of Gantour, Morocco (Chahi et al. 2002) or the palygorskite from other occurrences (Gionis et al. 2006, 2007).

\section{Thermal behavior (TG-DTA)}

Evidence of the removal of carbonates is given by the disappearance in TG-DTA thermograms of purified fraction of the complex endothermic event observed for raw clay in the temperature range $560-885{ }^{\circ} \mathrm{C}$ associated with a weight loss of about $23 \%$. TG-DTA thermograms of $\mathrm{Na}^{+}$exchanged fraction (Fig. 5) are typical to those reported in previous studies (Giustetto and Compagnoni 2011). They show an endothermic peak at about $100{ }^{\circ} \mathrm{C}$ associated with a mass loss of $4.4 \mathrm{wt} \%$ generally ascribed to the removal of both physisorbed water and a part of zeolitic $\mathrm{H}_{2} \mathrm{O}$. This weight loss is lower than the $6 \mathrm{wt} \%$ recorded for palygorskite from Montestrutto, Italy (Giustetto and Compagnoni 2011) and the $9 \mathrm{wt} \%$ reported for other palygorskite (Mifsud et al. 1978). This is probably due to the removal of a low amount of physisorbed water upon samples drying at $80{ }^{\circ} \mathrm{C}$ prior to thermal analysis. This might also indicate that this weight loss predominantly corresponds to zeolitic $\mathrm{H}_{2} \mathrm{O}$ and confirms a deficiency in zeolitic $\mathrm{H}_{2} \mathrm{O}$ of the palygorskite from Marrakech High Atlas. Another broad endothermic effect, observed between 160 and $300{ }^{\circ} \mathrm{C}$ with a maximum at around $230{ }^{\circ} \mathrm{C}$, is accompanied with a mass loss of about $3.6 \mathrm{wt} \%$. It is due to the removal of remaining zeolitic $\mathrm{H}_{2} \mathrm{O}$ with the first fraction of $\mathrm{Mg}$-coordinated $\mathrm{OH}_{2}$ $\left(\mathrm{M}_{3}\right.$ site $)$. This temperature is higher than that $\left(\approx 205^{\circ} \mathrm{C}\right)$ 
Fig. 5 Thermal gravimetry (a) and DTA thermograms (b) of raw clay (PK7) and its fine fraction $\left(\mathrm{Na}^{+}-\mathrm{PK} 7\right)$

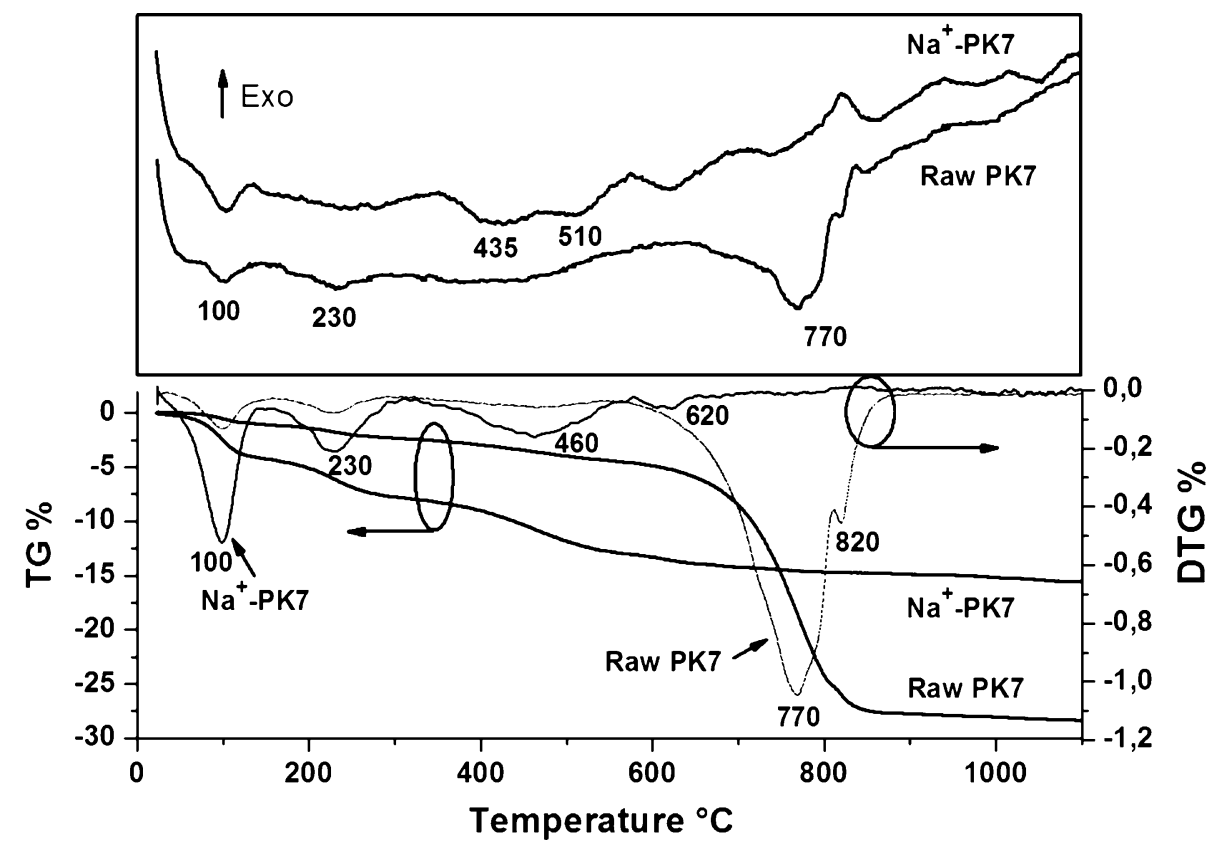

reported by Gionis et al. (2006) for palygorskites Gr1 from Pefkaki in Greece and PFl-1 originating from Gadsden County, Florida (USA). This difference could be explained by the presence of ca. $5 \%$ of sepiolite associated to palygorskite investigated herein, as revealed by XRD analysis, because this endothermic effect is found at higher temperature $\left(>250{ }^{\circ} \mathrm{C}\right)$ for sepiolite (Frost and Ding 2003; Giustetto et al. 2011). The global weight loss $(\approx 8 \%)$ recorded in the low-temperature range $\left(T<300{ }^{\circ} \mathrm{C}\right)$ is lower than previously reported values, for example, $12.5 \%$ (Giustetto and Chiari 2004) and $13.7 \%$ (Artioli et al. 1994), implying the occurrence of $\mathrm{H}_{2} \mathrm{O}$ deficit, mainly zeolitic $\mathrm{H}_{2} \mathrm{O}$, in our samples (Mifsud et al. 1978, Giustetto and Compagnoni 2011). The zeolitic $\mathrm{H}_{2} \mathrm{O}$ deficiency seems to be more pronounced in Marrakech High Atlas palygorskite by comparison with the palygorskite from Montestrutto, Italy (Giustetto and Compagnoni 2011: $\approx 9 \mathrm{wt} \%$ ).

Between 330 and $590{ }^{\circ} \mathrm{C}$, a broad endothermic peak, centered around $460{ }^{\circ} \mathrm{C}$, associated with mass loss of about $5.2 \%$ is attributed to the removal of the residual fraction of Mg-coordinated $\mathrm{OH}_{2}$ (Giustetto and Chiari 2004; Giustetto and Compagnoni 2011), which causes the collapse and the formation of "palygorskite anhydride" (Preisinger 1963 in Giustetto and Compagnoni 2011). In the high-temperature region $\left(T>600^{\circ} \mathrm{C}\right)$, an endothermic effect peaking at $620^{\circ} \mathrm{C}$ associated with supplementary weight loss around $2 \%$ is due to dehydroxylation resulting in the formation of clinoenstatite (Hayashi et al. 1969 in Giustetto and Compagnoni 2011). Finally, an exothermic effect observed at about $820^{\circ} \mathrm{C}$ is due to the crystallization of a new anhydrous mineral phase.
According to Caillère and Hénin 1961, the weight losses described above could be assigned to different kinds of water of palygorskite according to temperature ranges by assuming that zeolitic $\mathrm{H}_{2} \mathrm{O}$ is lost below $200{ }^{\circ} \mathrm{C}$, structural $\mathrm{OH}_{2}$ is lost between 250 and $400{ }^{\circ} \mathrm{C}$, and hydroxyl groups above $400{ }^{\circ} \mathrm{C}$. Nevertheless, other authors stated that the partitioning of these mass losses among different kinds of water is not so strict (Giustetto and Chiari 2004; Giustetto and Compagnoni 2011). As suggested by Giustetto and Compagnoni (2011), the $2 \mathrm{wt} \%$ decrease at high temperatures can indisputably be ascribed to the loss of framework hydroxyls, and $8 \mathrm{wt} \%$ among the remaining weight loss $(\approx 13 \mathrm{wt} \%)$ can be reasonably attributed to structural $\mathrm{OH}_{2}$, while $5 \mathrm{wt} \%$ may be related to zeolitic $\mathrm{H}_{2} \mathrm{O}$.

Tetrahedral versus octahedral occupation of $\mathrm{Si}^{4+}$ and $\mathrm{Al}^{3+}$ (MAS-NMR)

MAS-NMR spectroscopy did not reveal differences between the raw clay and its fine fraction. Typical ${ }^{27} \mathrm{Al}$-NMR spectrum (Fig. 6a) shows two peaks at 4.1 and 71.4 ppm corresponding to octahedral and tetrahedral $\mathrm{Al}$, respectively (Woessner 1989; Komarneni et al. 1986a, b). The peak at $4.1 \mathrm{ppm}$ appears significantly more intense than the peak at $71.4 \mathrm{ppm}$, which indicates, as expected, that Al principally occupies octahedral sheet, whereas only $5 \%$ of $\mathrm{Al}^{3+}$, deduced from peaks intensities ratio, occupies tetrahedral sheet. Typical ${ }^{29} \mathrm{Si}-\mathrm{NMR}$ spectrum (Fig. 6b) reveals a doublet of peaks at -91.7 and -96.8 ppm corresponding to two nonequivalent crystallographic sites of tetrahedral Si cations Q3(0Al) (Komarneni et al. 1986a, b). A small peak at $-84.9 \mathrm{ppm}$ likely corresponds to component Q3(1Al) (Komarneni et al. 1986a) confirming the substitution in 
(a)
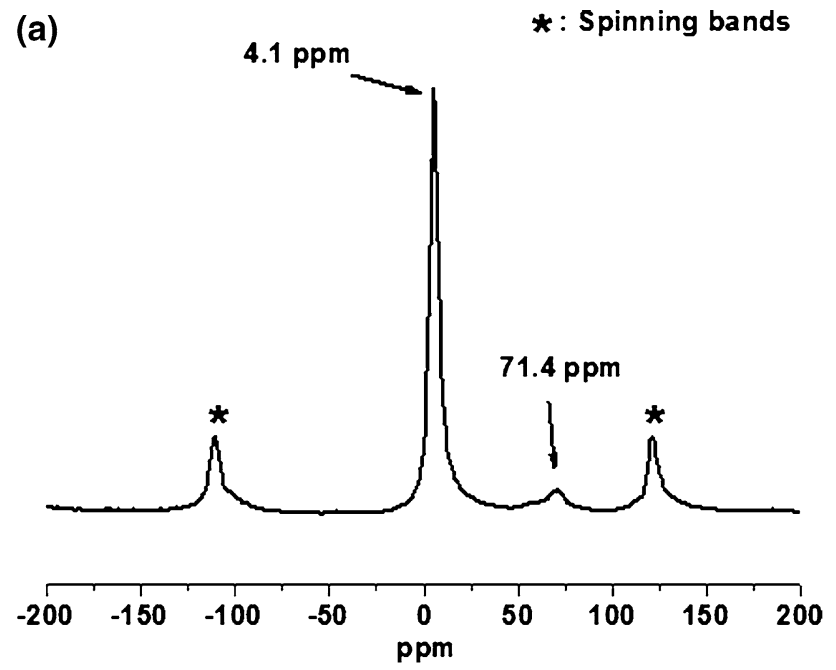

(b)

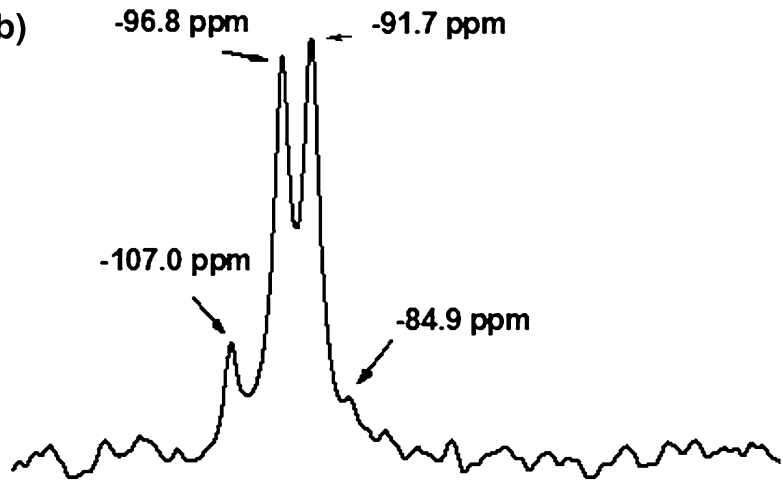

$-150$

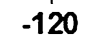

$-90$

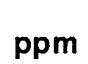

$-60$

$-30$

Fig. $6{ }^{27} \mathrm{Al}(\mathbf{a})$ and ${ }^{29} \mathrm{Si}(\mathbf{b})$ MAS-NMR spectra of $\mathrm{Na}^{+}$-PK7 $<2 \mu \mathrm{m}$ fraction

tetrahedral sheet of some $\mathrm{Si}^{4+}$ by $\mathrm{Al}^{3+}$. The peak at $-107.0 \mathrm{ppm}$ corresponds to quartz impurity (Lippmaa et al. 1980) which remains in the samples even after purification in agreement with XRD analysis.

\section{CEC and textural properties}

The CEC, determined from the adsorption of cobalt hexamine (III) complex onto $\mathrm{Na}^{+}$-Pal according to the literature method (Mantin and Glaeser 1960), is found to be around $21.2 \mathrm{meq} / 100 \mathrm{~g}$. This value is of the same order of magnitude than for palygorskite from Oman (19.2 meq/ $100 \mathrm{~g})$ and from Hawthorne, FL, USA (19.5 meq/100 g) (Al-Futaisi et al. 2007). Nevertheless, it is lower than those from other origins, for example, 25, 42.5, and $31 \mathrm{meq} /$ $100 \mathrm{~g}$ as reported by Serna et al. (1977), Blanco et al. (1989), and Chahi et al. (2002), respectively.

$\mathrm{N}_{2}$ adsorption-desorption isotherms on raw clay and its fine fraction reveal that they are similar of type II, with small hysteresis loops of type $\mathrm{H} 3$ according to the classification of the International Union of Pure and Applied Chemistry (IUPAC) (Sing et al. 1985) (Fig. 7). The shape of the isotherms denotes that both samples are mainly mesoporous solids, but also contain some micropores as clearly evidenced on the inset in Fig. 7 by the observation of a sharp increase at low pressure upon adsorption process. According to Cases et al. (1991), this microporosity is likely due to interfibers also revealed by SEM imaging (Fig. 3b), whereas channels could not be accessed to $\mathrm{N}_{2}$ species and hence corresponding structural microporosity could not be detected owing to structure folding of palygorskite caused by prior outgassing treatment at $150{ }^{\circ} \mathrm{C}$. The hysteresis of type $\mathrm{H} 3$ denotes that their particles form aggregates (Rouquerol et al. 2003). The BET specific surface area $\left(S_{\mathrm{BET}}\right)$ was determined from these isotherms, by applying BET equation for the relative pressure range $0.02<\mathrm{p} / \mathrm{p}_{0}<0.33$. The microporous surface area $\left(S_{\mathrm{mic}}\right)$, external surface area $\left(S_{\text {ext }}\right)$, and the micropore volume $\left(V_{\text {mic }}\right)$ were obtained by the t-plot method (de Boer et al. 1966). Meanwhile, the mesopore volume $\left(V_{\text {mes }}\right)$, the total pore volume $\left(V_{\mathrm{T}}\right)$, and pore size distribution were assessed according to the Barrett-Joyner-Halenda (BJH) method (Barett et al. 1951). The overall results gathered in Table 1 show that, according to outgassing conditions (Cases et al. 1991; Jones and Galan 1988), the specific surface area of palygorskite sensibly varies from 100.4 to $116 \mathrm{~m}^{2} / \mathrm{g}$ when the outgassing temperature used is 150 and $140{ }^{\circ} \mathrm{C}$, respectively. This value is still quite lower than the values reported in the literature, which are in the range 150-320 m²/g (Galán 1996).

\section{Chemical analysis (ICP)}

Chemical compositions of the dehydrated raw clay and its fine fraction indicate a huge decrease of $\mathrm{CaO}$ amount from about $37.6 \%$ in the raw clay to around $0.3 \%$ in the fine $\mathrm{Na}^{+}$-exchanged fraction (Table 2). Besides, the amount of potassium could be due to illite impurity existing in a minor amount associated to fibrous clay mineral as well as charge compensating cation in its channels. Illite was not detected by XRD analysis likely because of a proportion lower than the detection threshold and/or an overlapping of its characteristic $(001)$ reflection $(\approx 10 \AA)$ (Holtzapffel $1985)$ with the very intense (110) basal reflection of palygorskite occurring at a close distance $(10.56 \AA)$.

At this stage, the partitioning of the amount of $K$ among possible illite impurity and exchangeable compensating cation is not possible. The subtraction of the contribution of both sepiolite (assumed to be $5 \%$ ) and quartz (2\%) from the composition of fine $\mathrm{Na}^{+}$-exchanged fraction $\left(\mathrm{Na}^{+}\right.$-PK7) and taking into account the chemical mass balance relation (Hodgson and Dudeney 1984; Engler and 
Iyengar 1987; Bruand and Prost 1988; Bouabid and Badraoui 1996) yields to the elemental composition of dehydrated palygorskite $\left(\mathrm{Na}^{+}-\mathrm{Pal}\right)$ and the number of cations per 21 atoms (Table 2). The structural formula of dehydrated palygorskite determined by neglecting the contribution of $\mathrm{K}$ is approximately found to be $\left(\mathrm{Si}_{7.92} \mathrm{Al}_{0.08}\right)\left(\mathrm{Mg}_{2.15} \mathrm{Al}_{1.4} \mathrm{Fe}_{0.4} \mathrm{Ti}_{0.05} \square_{1}\right)\left(\mathrm{Ca}_{0.03} \mathrm{Na}_{0.08}\right) \mathrm{O}_{21}$. This formula shows that the tetrahedral occupation of $\mathrm{Al}$ represents $5 \%$ in good agreement with the proportion beforehand determined from the ratio $\mathrm{Al}^{\mathrm{IV}} /\left(\mathrm{Al}^{\mathrm{IV}}+\mathrm{Al}^{\mathrm{VI}}\right)$ of ${ }^{27} \mathrm{Al}$ MAS-NMR peaks intensities. With respect to the ideal formula $\mathrm{Si}_{8} \mathrm{Mg}_{5} \mathrm{O}_{20}(\mathrm{OH})_{2}\left(\mathrm{OH}_{2}\right)_{4}, 4\left(\mathrm{H}_{2} \mathrm{O}\right)$ proposed by Bradley (1940) for a pure trioctahedral palygorskite, the determined formula of the dehydrated palygorskite from Marrakech High Atlas shows excess of negative charges on tetrahedral and octahedral sheets of about -0.08 and -0.1

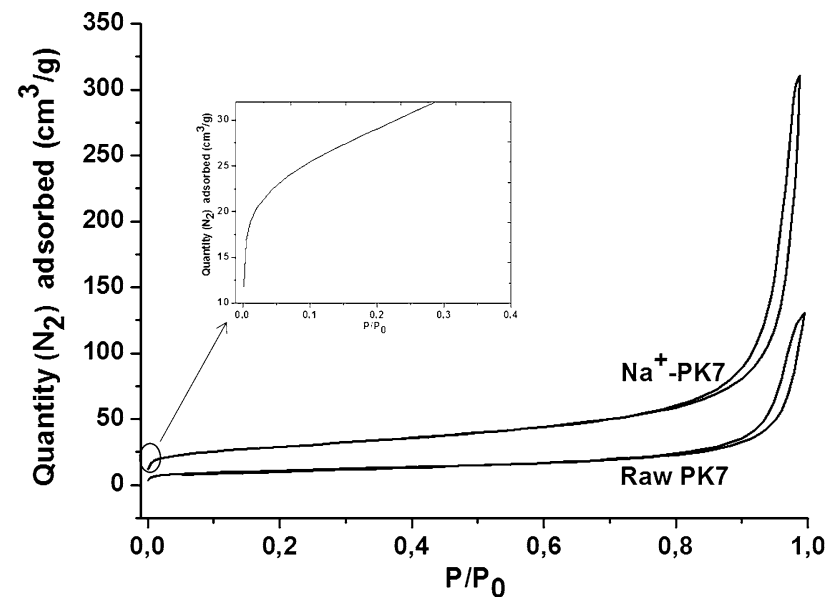

Fig. 7 Adsorption-desorption $\left(\mathrm{N}_{2}\right)$ isotherms of the raw clay (PK7) and the separated fine fraction $\left(\mathrm{Na}^{+}-\mathrm{PK} 7\right)$ e/half unit, respectively. They are compensated by a lower positive charge $\left(+0.14\right.$ e/half unit) due to $\mathrm{Ca}^{2+}$ and $\mathrm{Na}^{+}$ interlayer cations. This positive charge deficit could be completed by introducing 0.04 of exchangeable compensating $\mathrm{K}^{+}$ions to ensure the electrical neutrality of the overall formula. This deduced amount of $\mathrm{K}^{+}$corresponds to $0.23 \mathrm{wt} \%$ of $\mathrm{K}_{2} \mathrm{O}$ which is of the same order of magnitude than those reported to be usually contained in several palygorskites from other areas (Chahi et al. 2002; GarciaRomero and Suárez 2010). Hence, the most appropriate chemical formula per half unit cell of the dehydrated palygorskite investigated herein, deduced on the basis of 21 oxygens, could be $\left(\mathrm{Si}_{7.92} \mathrm{Al}_{0.08}\right)\left(\mathrm{Mg}_{2.15} \mathrm{Al}_{1.4} \mathrm{Fe}_{0.4} \mathrm{Ti}_{0.05} \square_{1}\right)$ $\left(\mathrm{Ca}_{0.03} \mathrm{Na}_{0.08} \mathrm{~K}_{0,04}\right) \mathrm{O}_{21}$.

The structural formula of the hydrated palygorskite, calculated on the basis of 26 oxygens by taking into account the experimental amounts of different kinds of water determined above by TG (Caillère and Hénin 1961), is $\left(\mathrm{Si}_{7.97} \mathrm{Al}_{0.03}\right)\left(\mathrm{Mg}_{2.17} \mathrm{Al}_{1.46} \mathrm{Fe}_{0.40} \mathrm{Ti}_{0.05}\right)\left(\mathrm{Ca}_{0.03} \mathrm{Na}_{0.07} \mathrm{~K}_{0,03}\right)$ $\mathrm{O}_{20.18}(\mathrm{OH})_{1.94}\left(\mathrm{OH}_{2}\right)_{3.88} \cdot 2.43 \quad \mathrm{H}_{2} \mathrm{O}$. This crystal-chemical formula shows that the octahedral sheet composition exhibits a predominant dioctahedral character with divalent to trivalent cation ratio $\mathrm{R}\left(\mathrm{Al}^{3+}+\mathrm{Fe}^{3+}\right) / \mathrm{R}_{\left(\mathrm{Mg}^{2+}\right)}$ around 0.84 . Besides, the same formula evidences the above commented deficiency of zeolitic $\mathrm{H}_{2} \mathrm{O}$ (2.43 molecules per crystal-chemical formula instead of 4 ), as inferred by TGA data. The $\mathrm{M}_{2}$ sites linked to structural $\mathrm{OH}$ seem to be predominantly occupied at $90 \%$ by trivalent cations, that is, $\mathrm{Al}^{3+}(78 \%)$ and $\mathrm{Fe}^{3+}(22 \%)$, at $7.5 \%$ by divalent cations $\mathrm{Mg}^{2+}$ and at $2.5 \%$ by tetravalent cations $\mathrm{Ti}^{4+}$.

On the basis of all octahedral cations occupation percentages determined herein on the one hand and knowing that palygorskite octahedral sheet contains 10 charges per half-cell on the other hand, a qualitative octahedral cation distribution for the palygorskite from Marrakech High

Table 1 BET specific surface area $\left(\mathrm{S}_{\mathrm{BET}}\right)$, total pore volume $\left(\mathrm{V}_{\mathrm{T}}\right)$, microporous volume $\left(\mathrm{V}_{\text {mic }}\right)$, mesoporous volume $\left(\mathrm{V}_{\text {mes }}\right)$, macroporous volume $\left(\mathrm{V}_{\mathrm{mac}}\right)$, micropore surface area $\left(\mathrm{S}_{\mathrm{mic}}\right)$, and external surface area $\left(\mathrm{S}_{\text {ext }}\right)$ of the raw clay $(\mathrm{PK} 7)$ and its purified $<2 \mu \mathrm{m}$ fraction $\left(\mathrm{Na}{ }^{+}\right.$-PK7)

\begin{tabular}{|c|c|c|c|c|c|c|c|}
\hline Clay & $\begin{array}{l}S_{\mathrm{BET}} \\
\left(\mathrm{m}^{2} / \mathrm{g}\right)\end{array}$ & $\begin{array}{l}\text { Total pore } \\
\text { volume, } \\
V_{\mathrm{T}}\left(\mathrm{cm}^{3} / \mathrm{g}\right)\end{array}$ & $\begin{array}{l}\text { Micropores } \\
\text { volume, } V_{\text {mic }} \\
\left(\mathrm{cm}^{3} / \mathrm{g}\right)\end{array}$ & $\begin{array}{l}\text { Mesopores } \\
\text { volume, } V_{\text {mes }} \\
\left(\mathrm{cm}^{3} / \mathrm{g}\right)\end{array}$ & $\begin{array}{l}\text { Macropores } \\
\text { volume, } V_{\mathrm{mac}} \\
\left(\mathrm{cm}^{3} / \mathrm{g}\right)\end{array}$ & $\begin{array}{l}\text { Micropores surface } \\
\text { area, } S_{\text {mic }}\left(\mathrm{m}^{2} / \mathrm{g}\right)\end{array}$ & $\begin{array}{l}\text { External surface } \\
\text { area, } S_{\text {ext }}\left(\mathrm{m}^{2} / \mathrm{g}\right)\end{array}$ \\
\hline Raw PK7 & 38.4 & $0.1937^{\mathrm{d}}$ & $0.0004^{\mathrm{g}}$ & $0.0693^{\mathrm{e}}$ & $0.1224^{f}$ & 4.2 & $34.2^{\mathrm{g}}$ \\
\hline \multirow[t]{3}{*}{$\mathrm{NA}^{+}-\mathrm{PK} 7$} & $100.4^{\mathrm{a}}$ & $0.4581^{\mathrm{d}}$ & $0.0020^{\mathrm{g}}$ & $0.1632^{\mathrm{e}}$ & $0.2927^{f}$ & 12.2 & $88.2^{\mathrm{g}}$ \\
\hline & $112.7^{\mathrm{b}}$ & & & & & 12 & $100.7^{\mathrm{g}}$ \\
\hline & $116.7^{\mathrm{c}}$ & & & & & 22.9 & $93.8^{\mathrm{g}}$ \\
\hline
\end{tabular}

\footnotetext{
${ }^{a} S_{\text {BET }}$ determined by outgassing sample at $150^{\circ} \mathrm{C}$ for $24 \mathrm{~h}$

b $S_{\text {BET }}$ determined by outgassing sample at $150{ }^{\circ} \mathrm{C}$ for $12 \mathrm{~h}$

${ }^{\mathrm{c}} S_{\mathrm{BET}}$ determined by outgassing sample at $140^{\circ} \mathrm{C}$ for $9 \mathrm{~h}$

${ }^{\mathrm{d}}$ Determined from BJH adsorption cumulative pore volume of pores having diameters in the range 17.0-3000.0

e Determined from BJH adsorption cumulative pore volume data for pores having diameters in the range 20.0-500.0

${ }^{\mathrm{f}}$ Determined from BJH adsorption cumulative pore volume data for pores having diameters above $500.0 \AA$

g Determined from the $t$-curve (adsorbed volume, $V_{\text {ads }}$ vs. the thickness $t$ )
} 
Table 2 Chemical compositions of the raw clay (PK7) and its $<2 \mu \mathrm{m}$ fine fraction $\left(\mathrm{Na}^{+}-\mathrm{PK} 7\right)$

\begin{tabular}{lllll}
\hline $\begin{array}{l}\text { Samples } \\
\text { Oxides }\end{array}$ & $\begin{array}{l}\text { Raw clay (PK7) } \\
\text { Wt } \%\end{array}$ & $\begin{array}{l}\mathrm{Na}^{+}-\mathrm{PK} 7(0.2 \mathrm{~N}) \\
\mathrm{Wt} \%\end{array}$ & $\begin{array}{l}\mathrm{Na}^{+} \mathrm{Pal} \\
\mathrm{Wt} \%\end{array}$ & $\begin{array}{l}\text { Cations } \\
\text { number/ } \\
\text { half-cell }\end{array}$ \\
\hline $\mathrm{SiO}_{2}$ & 33.00 & 66.26 & 64.29 & 7.92 \\
$\mathrm{Al}_{2} \mathrm{O}_{3}$ & 8.35 & 9.83 & 10.23 & 1.48 \\
$\mathrm{Fe}_{2} \mathrm{O}_{3}$ & 4.00 & 4.18 & 4.32 & 0.40 \\
$\mathrm{MgO}$ & 11.76 & 2.51 & 11.74 & 2.15 \\
$\mathrm{CaO}$ & 37.62 & 0.27 & 0.26 & 0.03 \\
$\mathrm{Na}{ }_{2} \mathrm{O}$ & 0.65 & 0.32 & 0.32 & 0.08 \\
$\mathrm{~K}_{2} \mathrm{O}$ & 1.37 & 2.01 & 2.01 & - \\
$\mathrm{TiO}_{2}$ & 0.28 & 0.60 & 0.60 & 0.05 \\
$\mathrm{LOI}_{\mathrm{Total}}$ & 2.97 & 4.04 & 6.23 & - \\
\hline
\end{tabular}

Atlas could be illustrated by considering 10 unit cells as in Fig. 8. In this distribution, the rate of hydroxyl groups linked to $\mathrm{M}_{2}$ sites seems to increase as a function of octahedral cations as follows:

$$
\begin{aligned}
& \mathrm{Al}_{2} \mathrm{OH}(60 \%)>\mathrm{Fe}_{2} \mathrm{OH}(15 \%)>\operatorname{AlFeOH}(10 \%) \\
& \quad \approx \operatorname{AlMgOH}(10 \%)>\operatorname{TiMgOH}(5 \%)
\end{aligned}
$$

The CEC corresponding to the compensating cations charge $\xi(+0.16$ e/half unit cell) exhibited by the structural formula above can be calculated from the following Eq. (1) (Besson et al. 1990; Mermut and Lagaly 2001):

$\mathrm{CEC}=10^{5} \times \xi / M$

where $M$ designates the molar mass. The calculated value about $20 \mathrm{meq} / 100 \mathrm{~g}$ is quite similar to the experimental value measured from cobalt hexamine adsorption.

\section{Octahedral sheet composition (IR)}

As beforehand revealed by XRD analysis (Fig. 4a) and thermal analysis (Fig. 5), the MIR spectra of the raw clay and its fine $\mathrm{Na}^{+}$-exchanged fraction confirm the entire removal of carbonates impurities largely present in the raw clay upon the purification treatment as evidenced by the disappearance of corresponding bands at 1,440, 870, and $714 \mathrm{~cm}^{-1}$ (Fig. 9a). Except for these differences, the MIR spectra of the two samples reveal similar absorption bands which are better resolved by superposing the corresponding second-derivative spectra (Fig. 9a).

The octahedral sheet composition deduced above is further strongly supported by IR spectroscopy in middle and near frequencies regions which generally gives evidence for strong vibration bands of $\mathrm{Al}_{2} \mathrm{OH}$ and relatively small peaks of $\mathrm{Fe}_{2} \mathrm{OH}$ and $\mathrm{AlFeOH}$. Indeed, the bands at $3,618,3,555$, and $3,580 \mathrm{~cm}^{-1}$ are due to the stretching $\mathrm{OH}$ vibrations in $\mathrm{Al}_{2} \mathrm{OH}$ and/or of $\mathrm{Mg}$-coordinated $\mathrm{OH}_{2}$,
$\mathrm{Fe}_{2} \mathrm{OH}$, and $\mathrm{AlFeOH}$ and/or $\mathrm{AlMgOH}$ species, respectively (Serna et al. 1977; Blanco et al. 1989; Gionis et al. 2006, 2007). Nevertheless, the contribution of $\mathrm{AlMgOH}$ seems to be very minor since the above determined structural formula shows very low amount of $\mathrm{Mg}$ in central positions $\left(\mathrm{M}_{2}\right.$ site) of octahedral sheet. Their corresponding deformation vibrations' bands are neatly observed at 910, 800, and $780 \mathrm{~cm}^{-1}$, respectively (Gionis et al. 2006, 2007). These assignments are further confirmed in the secondderivative NIR spectrum of the fine $\mathrm{Na}^{+}$-exchanged fraction by the presence of a well-resolved triplet of bands at $7,059,7,000$, and $6,926 \mathrm{~cm}^{-1}$ (Fig. 9b) corresponding to the first overtones of the $\mathrm{O}-\mathrm{H}$ stretching modes $\left(2 v_{\mathrm{OH}}\right)$ of $\mathrm{Al}_{2} \mathrm{OH}, \mathrm{AlFeOH}$, and $\mathrm{Fe}_{2} \mathrm{OH}$ entities, respectively (Gionis et al. 2006, 2007).

Furthermore, their corresponding stretching-deformation combination vibrations are also well detected in the second-derivative NIR spectrum at 4,498, 4,431, and $4,340 \mathrm{~cm}^{-1}$, respectively (Fig. 9b). The observation of an additional well-defined peak at $3,684 \mathrm{~cm}^{-1}$ (Fig. 9a) is worth noting. It likely corresponds to the stretching vibration of $\mathrm{OH}$ in $\mathrm{Mg}_{3} \mathrm{OH}$ species (Chahi et al. 2002). The corresponding deformation band is observed at $680 \mathrm{~cm}^{-1}$, while its corresponding first overtone of the $\mathrm{O}-\mathrm{H}$ stretching vibration is clearly observed at $7,215 \mathrm{~cm}^{-1}$ in the second-derivative NIR spectrum (Fig. 9b). A broad peak centered at around $1,650 \mathrm{~cm}^{-1}$ is observed whose second derivative reveals that it is made up of two well-resolved peaks at 1,640 and $1,660 \mathrm{~cm}^{-1}$ (Fig. 9a), assigned to coordinated and zeolitic $\mathrm{H}_{2} \mathrm{O}$ present in palygorskite according to Gionis et al. (2006) and Gionis et al. (2007). A third band at $1,675 \mathrm{~cm}^{-1}$, ascribed by these authors to physisorbed water, is not observed in the samples investigated herein likely because of their preparation (storage and drying) prior analysis. However, the corresponding stretching vibrations bands that are more sensitive are clearly observed at 3,270 and $3,430 \mathrm{~cm}^{-1}$ in the two samples.

Furthermore, the second-derivative NIR spectrum of the $\mathrm{Na}^{+}$-PK7 sample also reveals the presence of a main peak at $5,210 \mathrm{~cm}^{-1}$ and a shoulder at $5,045 \mathrm{~cm}^{-1}$ due to combination modes of the three types of $\mathrm{H}_{2} \mathrm{O}$ (physisorbed, zeolitic, and coordinated to edge cations) characteristic of palygorskite. The bands at 1200 and $646 \mathrm{~cm}^{-1}$ are fingerprints of fibrous clay minerals as palygorskite and sepiolite. They correspond to the asymmetric and symmetric stretching of the $\mathrm{Si}-\mathrm{O}-\mathrm{Si}$ bridges linking the aluminosilicate slabs of these fibrous clay minerals (Gionis et al. 2006). The corresponding deformation vibration band clearly appears at $428 \mathrm{~cm}^{-1}$. The band at $1,093 \mathrm{~cm}^{-1}$ could be ascribed to stretching vibrations of $\mathrm{Al}-\mathrm{O}$ in octahedral sheet (Blanco et al. 1989). The absorption bands at 1,028 and $985 \mathrm{~cm}^{-1}$ are characteristic of antisymmetric 


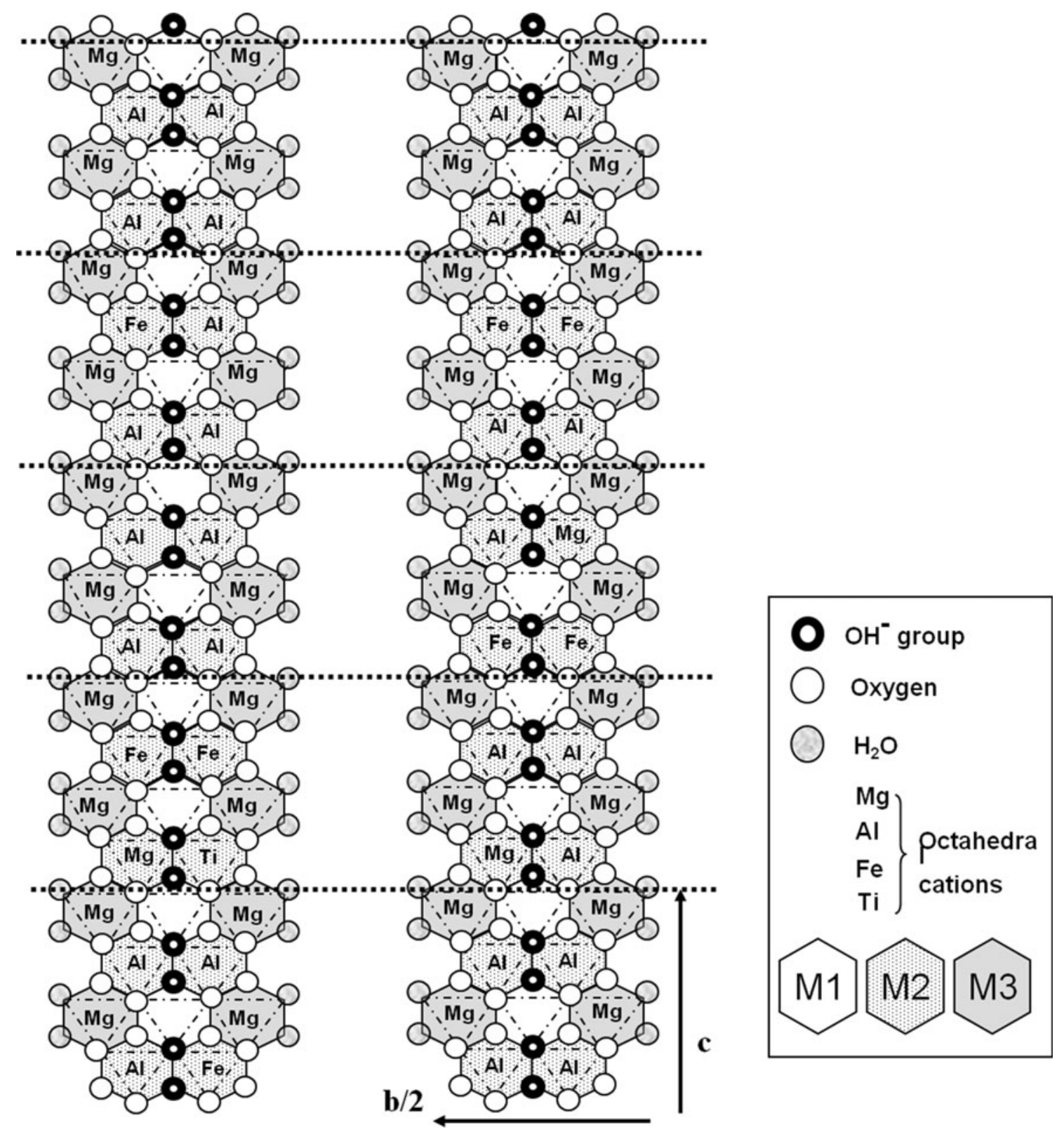

Fig. 8 Schematic distribution of cations in the octahedral sheet of ten units of palygorskite from Marrakech High Atlas [projection on the (100) plane] showing that the 20 most inner $\mathrm{M}_{1}$ sites were vacant and the following $40 \mathrm{M}_{2}$ sites were shared between $28 \mathrm{Al}^{3+}, 8 \mathrm{Fe}^{3+}$, $3 \mathrm{Mg}^{2+}$, and $1 \mathrm{Ti}^{4+}$, while the $40 \mathrm{M}_{3}$ sites at the edges were all occupied par $\mathrm{Mg}^{2+}$ vibrations of $\mathrm{Si}-\mathrm{O}$ and $\mathrm{Al}-\mathrm{O}$ in tetrahedral sheet of palygorskite (Augsburger et al. 1998; Suárez and GarcíaRomero 2006). The corresponding deformation vibration bands are clearly observed at 474 and $580 \mathrm{~cm}^{-1}$ for $\mathrm{Si}-\mathrm{O}$ bonds. The peak at $509 \mathrm{~cm}^{-1}$ is also observed by Suárez and García-Romero (2006) for Al-rich palygorskites; it is ascribed to vibrations of $\mathrm{Al}-\mathrm{O}-\mathrm{Si}$ in tetrahedral sheet. These results denote the substitution of $\mathrm{Al}^{3+}$ for $\mathrm{Si}^{4+}$ in tetrahedral sheet as also revealed by NMR analysis (Fig. 6) and the determined structural formula.

\section{Conclusions}

This study demonstrates that the fine fraction $(<2 \mu \mathrm{m})$ isolated from clay, picked up in Marrakech High Atlas (Morocco), is rich in palygorskite (95\%) along with minor amount of sepiolite (5\%). The crystal-chemistry formula of this palygorskite has been determined as: $\left(\mathrm{Si}_{7.97} \mathrm{Al}_{0.03}\right)$ $\left(\mathrm{Mg}_{2.17} \mathrm{Al}_{1.46} \mathrm{Fe}_{0.40} \mathrm{Ti}_{0.05}\right)\left(\mathrm{Ca}_{0.03} \mathrm{Na}_{0.07} \mathrm{~K}_{0,03}\right) \mathrm{O}_{20.18}(\mathrm{OH})_{1.94}$ $\left(\mathrm{OH}_{2}\right)_{3.88} \cdot 2.43 \mathrm{H}_{2} \mathrm{O}$. This shows a deficiency in zeolitic $\mathrm{H}_{2} \mathrm{O}$ (5 wt $\%$ ) which seems to be more pronounced than for 
Fig. 9 Mid-infrared spectra (a) and near-infrared spectra (b) of clay samples before (PK7) and after the purification treatment $\left(\mathrm{Na}^{+}-\mathrm{PK} 7\right)$ (a)

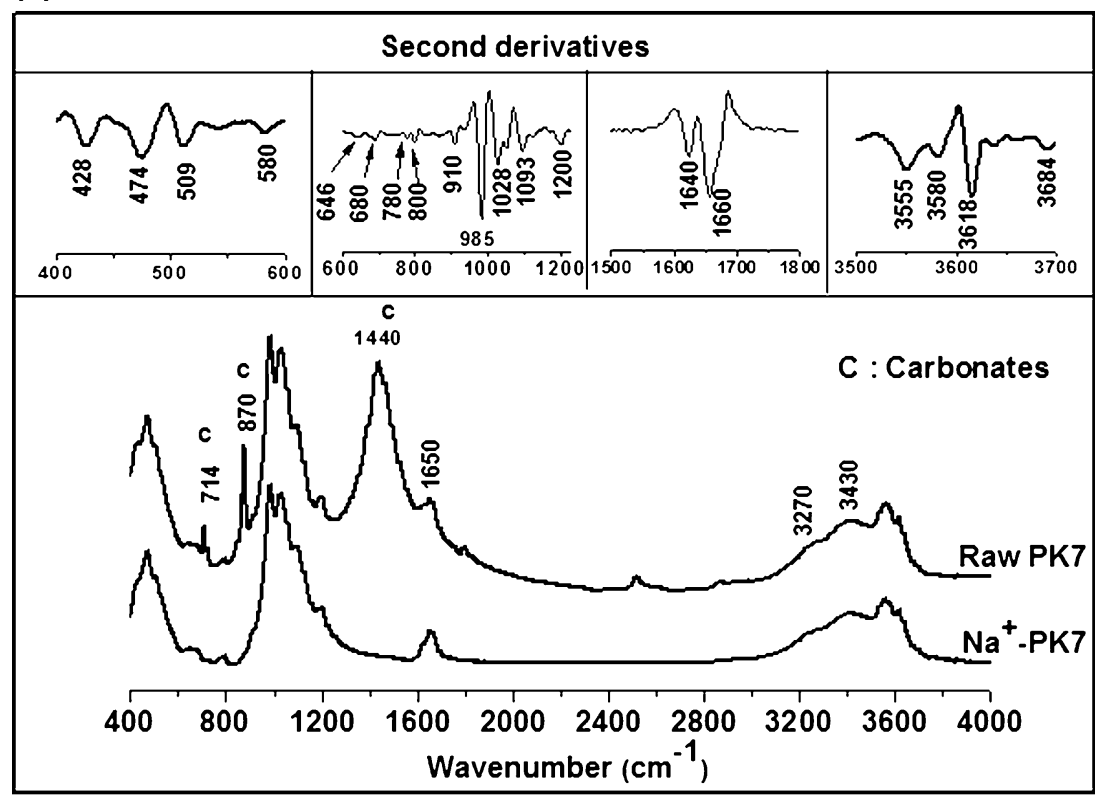

(b)

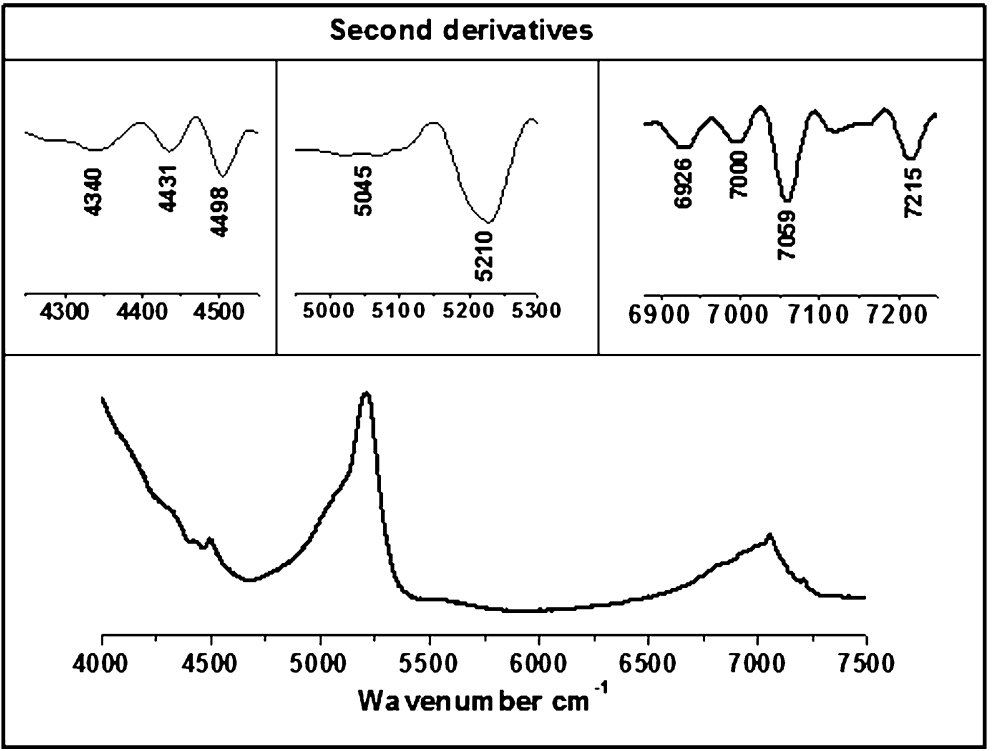

palygorskite from Montestrutto, Italy (Giustetto and Compagnoni 2011: $6 \mathrm{wt} \%)$. Besides, the ratio $\left(\mathrm{Al}^{3+}+\mathrm{Fe}^{3+}\right) /$ $\mathrm{Mg}^{2+}$ of about 0.84 , inferred from the chemical composition of octahedral sheet, indicates a pronounced dioctahedral character of this palygorskite in contrast with the palygorskite from phosphorite deposits of Gantour (Morocco) exhibiting a mixture of di- and trioctahedral property (Chahi et al. 2002). This is further supported by the observation of intense fundamental $\mathrm{OH}$ stretching modes in MIR spectra as well as their corresponding first overtones in NIR spectra arising from mainly $\mathrm{Al}_{2} \mathrm{OH}$ units along with those relatively less intense of $\mathrm{Fe}_{2} \mathrm{OH}$ and $\mathrm{AlFeOH}$ groups. On the basis of these premises, a scheme (Fig. 8), elucidating the octahedral sheet composition of palygorskite from Marrakech High Atlas, was proposed. Its functional features, in terms of cation exchange capacity, specific surface area, and total pore volume, were also assessed to be about $21.2 \mathrm{meq} / 100 \mathrm{~g}$, $116 \mathrm{~m}^{2} / \mathrm{g}$, and $0.46 \mathrm{~cm}^{3} / \mathrm{g}$, respectively.

Acknowledgments The financial supports from the "Convention de coopération CNRST-Maroc/CNRS-France" (chemistry project $\mathrm{N}^{\circ}$ 04/08), the "Programme de Coopération Scientifique Interuniversitaire de l'Agence Universitaire de la Francophonie" $\left(\mathrm{N}^{\circ} 63\right.$ 13PS826), the "Programme d'Action Intégrée Volubilis" ( $\mathrm{N}^{\circ} \mathrm{MA}-$ 08-185), and "Convention de coopération Académie Hassan II des Sciences et Techniques-Maroc/CSIC-Espagne" (Project AH11STConvention-nano 2011-2012) are gratefully acknowledged. 


\section{References}

Aït Aghzzaf A, Rhouta B, Steinmetz J, Rocca E, Aranda L, Khalil A, Yvon J, Daoudi L (2012) Corrosion inhibitors based on chitosanheptanoate modified beidellite. Appl Clay Sci 65-66:173-178

Al-Futaisi A, Jamrah A, Al-Rawas A, Al-Hanai S (2007) Adsorption capacity and mineralogical and physico-chemical characteristics of Shuwaymiyah palygorskite (Oman). Environ Geol 51:13171327

Artioli G, Galli E (1994) The crystal structures of orthorhombic and monoclinic palygorskite. Mater Sci Forum 166-169:647-652

Artioli G, Galli E, Burattini E, Cappuccio G, Simeoni S (1994) Palygorskite from Bolca, Italy: a characterization by highresolution synchrotron radiation powder diffraction and computer modelling. N Jb Miner Mh 5:217-229

Augsburger MS, Strasser E, Perino E, Mercader RC, Pedregosa JC (1998) FTIR and Mössbauer investigation of a substituted palygorskite: silicate with a channel structure. J Phys Chem Solids 59:175-180

Bailey SW (1980) Structures of layer silicates. In: GW Brindley, G Brown (eds) Crystal structures of clay minerals and their X-ray identification. Mineral Society Monograph S, pp 1-123

Barett EP, Joyner LG, Halenda PF (1951) The determination of pore volume and area distribution in porous substances. Computation of nitrogen isotherms. J Am Chem Soc 73:373-380

Ben Aboud A, Lopez Galindo A, Fenoll Hach-Ali P, Chellai EH, Daoudi L (1996) The presence, genesis and significance of palygorskite in some Moroccan Tertiary sequences. In: Ortega M, López-Galindo A, Palomo I (eds) Advances in clay minerals. Spanish-Italian Meeting on Clay Minerals, Granada, pp 87-89

Besson G, Decarreau A, Manceau A, Sanz J, Suquet H (1990) Organisation interne du feuillet. In Matériaux argileux: structures, propriétés et applications. In: Decarreau A (ed) Société Française de Minéralogie et de Cristallographie et Groupe Français des Argiles, pp 5-25

Blanco C, Gonzalez F, Pesquera C, Benito I, Mendioroz S, Pakhares JA (1989) Differences between one palygorskite and another magnesic by infrared spectroscopy. Spectrosc Lett 22:659-673

Bouabid R, Badraoui M (1996) QuantArg1: un modèle pour la quantification des minéraux argileux dans les sols et les sédiments. Hommes, Terre et Eaux 101:48-56

Bouna L, Rhouta B, Amjoud M, Maury F, Lafont MC, Jada A, Senocq F, Daoudi L (2011) Synthesis, characterization and photocatalytic activity of $\mathrm{TiO}_{2}$ supported natural palygorskite microfibers. Appl Clay Sci 52:301-311

Bouna L, Rhouta B, Daoudi L, Maury F, Amjoud M, Senocq F, Lafont MC, Jada A, Aït Aghzzaf A (2012) Mineralogical and physico-chemical characterizations of ferruginous beidellite-rich clay from Agadir basin (Morocco). Clay Clay Miner 60:278-290

Bradley WF (1940) The structural scheme of attapulgite. Am Mineral 25:405-410

Bruand A, Prost R (1988) Analyse minéralogique quantitative d'un échantillon de sol: utilisation des données concernant la composition chimique de l'échantillon. Agronomie 8:15-22

Brunauer S, Emmet PH, Teller E (1938) Adsorption of gases in multimolecular layers. J Am Ceram Soc 60:309-319

Caillère S, Hénin S (1961) Palygorskite. In: G.W. Brindley, G. Brown (eds) X-ray identification and crystal structure of clay minerals. Mineralogical Society, Monograph 5, London. pp 343-353

Caillere S, Hénin S, Rautureau M (1982) Minéralogie des argiles, tome 1: structures et proprieties physic-chimiques. Ed Masson, Paris

Cases JM, Grillet Y, François M, Michot L, Villiéras F, Yvon J (1991) Evolution of the porous structure and surface area of Palygorskite under vacuum thermal treatment. Clays Clay Miner 39(2):191-201
Chahi A, Petit S, Decarreau A (2002) Infrared evidence of dioctahedral-trioctahedral site occupancy in palygorskite. Clay Clay Miner 50:306-313

Chellai EH, Marzoqi M, Pascal A, Mouflih M (1995) Stratigraphy and evolution of upper cretaceous-paleogene sedimentary systems in the Marrakech High Atlas (Morocco). C. R. Acad Sci II A, Paris 321:745-752

Chisholm JE (1990) An X-ray powder-diffraction study of palygorskite. Can Mineral 28:329-339

Chisholm JE (1992) Powder diffraction patterns and structural models for palygorskite. Can Mineral 30:61-73

Christ CL, Hathaway JC, Hostetler PB, Shepard AO (1969) Palygorskite: new X- ray data. Am Mineral 54:198-205

Daoudi L (2004) Palygorskite in the uppermost Cretaceous-Eocene Rocks from Marrakech high Atlas, Morocco. J Afr Earth Sci 39:353-358

Daoudi L, Deconninck JF (1994) Contrôles paléogéographique et diagénétique des successions sédimentaires argileuses du bassin atlasique au Crétacé (Haut Atlas occidental, Maroc). J Afr Earth Sci 18:123-134

De Boer JM, Lippens BC, Linsen BG, Broekhoff JCP, Van der Heuvel A, Osinga TJ (1966) The t-curve of multimolecular N2 adsorption. J Colloid Interf Sci 21:405-414

Engler P, Iyengar SS (1987) Analysis of mineral samples using combined instrument (XRD, TGA, ICP) procedures for phase quantification. Am Mineral 72:832-838

Fernández ME, Ascencio JA, Mendoza-Anaya D, Rodriguez Lugo V, José-Yacamán M (1999) Experimental and theoretical studies of palygorskite clays. J Mater Sci 34:5243-5255

Frost RL, Ding Z (2003) Controlled thermal analysis and differential scanning calorimetry of sepiolites and palygorskites. Thermochim Acta 397:119-128

Galán E (1996) Properties and applications of palygorskite-sepiolite clays. Clay Miner 31:443-445

Galán E, Carretero I (1999) A new approach to compositional limits for sepiolite and palygorskite. Clay Clay Miner 47:399-409

Galán E, Mesa JM, Sanchez C (1994) Properties and applications of palygorskite clays from Ciudad Real, Central Spain. Appl Clay Sci 9:293-302

Galhano C, Rocha F, Gomes C (1999) Geostatistical analysis of the influence of textural, mineralogical and geochemical parameters on the geotechnical behaviour of the "Argilas de Aveiro" formation (Portugal). Clay Miner 34:109-116

Garcia-Romero E, Suárez M (2010) On the c30 chemical composition of sepiolite and palygorskite. Clay Clay Miner 58:1-20

Garcia-Romero E, Suarez M, Santaren J, Alvarez A (2007) Crystallochemical characterization of the palygorskite and sepiolite from the Allou Kagne deposit, Senegal. Clays Clay Miner 55:606-617

Gionis V, Kacandes GH, Kastritis ID, Chryssikos GD (2006) On the structure of palygorskite by mid- and near-infrared spectroscopy. Am Mineral 91:1125-1133

Gionis V, Kacandes GH, Kastritis ID, Chryssikos GD (2007) Combined near-infrared and X-ray diffraction investigation of the octahedral sheet composition of palygorskite. Clay Clay Miner 55:543-553

Giustetto R, Chiari G (2004) Crystal structure refinement of palygorskite from neutron powder diffraction. Eur $\mathrm{J}$ Mineral 16:521-532

Giustetto R, Compagnoni R (2011) An unusual occurrence of palygorskite from Montestrutto, Sesia-Lanzo Zone, Internal Western Alps (Italy). Clay Miner 46:371-385

Giustetto R, Wahyudi O, Corazzari I, Turci F (2011) Chemical stability and dehydration behavior of a sepiolite/indigo Maya Blue pigment. Appl Clay Sci 52:41-50 
Goodman BA, Russel JD, Fraser AR (1976) A Mössbaauer and IR spectroscopic study of the structure of nontronite. Clay Clay Miner 24:53-59

Güven N, Caillere JPE, Fripiat JJ (1992) The coordination of aluminium ions in the palygorskite structure. Clay Clay Miner 40:457-461

Hayashi H, Otsuka R, Imai N (1969) Infrared study of sepiolite and palygorskite on heating. Am Miner 54:1613-1624

Hodgson M, Dudeney AWL (1984) Estimation of clay proportions in mixtures by X-ray diffraction and computerized chemical mass balance. Clay Clay Miner 32:19-28

Holtzapffel T (1985) Les minéraux argileux : préparation, analyse diffractométrique et détermination. Société Géologique du Nord $12: 15-43$

Huang YJ, Li Z, Li SZ, Shi ZL, Yin L, Hsia YF (2007) Mössbauer investigations of palygorskite from Xuyi, China. Nucl Instrum Meth B 260:657-662

Jones BF, Galan E (1988) Palygorskite and sepiolite. In: Bailey SW (ed) Hydrous phyllosilicates-reviews in mineralogy 19. Mineralogical Society of America, Washington, pp 631-674

Komarneni S, Fyfe CA, Kennedy GJ (1986a) Detection of nonequivalent $\mathrm{Si}$ sites in sepiolite and palygorskite by solid-state $29 \mathrm{Si}$ Magic-Angle Spinning-Nuclear magnetic resonance. Clay Clay Miner 34:99-102

Komarneni S, Fyfe CA, Kennedy G, Strobl H (1986b) Characterization of synthetic and naturally occurring clays by $27 \mathrm{Al}$ and $29 \mathrm{Si}$ Magic-Angle Spinning NMR spectroscopy. J Am Ceram Soc 69:C45-C47

Krekeler MPS, Guggenheim S (2008) Defects in microstructures in palygorskite-sepiolite minerals: a transmission electron microscopy (TEM) study. Appl Clay Sci 39:98-105

Li X, Ni C, Yao C, Chen Z (2012) Development of attapulgite/Ce ${ }_{1-x}$ $\mathrm{Zr}_{\mathrm{x}} \mathrm{O}_{2}$ nanocomposite as catalyst for the degradation of methylene blue. Appl Catal B-Environ 117-118:118-124

Lippmaa E, Magi M, Samoson A, Engelhardt G, Grimmer A (1980) Structural studies of silicates by solid state high resolution Si-29 NMR. J Am Ceram Soc 102:4889-4893

Liu H, Chen T, Chang D, Chen D, He H, Yuan P, Xie J, Frost RL (2012) Characterization and catalytic performance of $\mathrm{Fe}_{3} \mathrm{Ni}_{8} /$ palygorskite for catalytic cracking of benzene. Appl Clay Sci. doi:10.1016/j.clay.2012.04.005

Mantin I, Glaeser R (1960) Fixation des ions cobalt hexamine par les montmorillonites acides. Bulletin du Groupe Français des Argiles 50:83-88

Marzoqi M (1990) Les systèmes sédimentaires marins paléogènes d'Ait Ourir: Séquences de faciés-Modèle de paléomilieuxGéochimie des carbonates-Approche austatique. PhD thesis Cadi Ayyad University Marrakech Morocco. p 274

Mehra OP, Jackson ML (1956) Iron oxide removal from soils and clays by a dithionide-citrate system buffered with sodium bicarbonate. Seventh national conference on clays and clay minerals. pp 317-327

Mermut AR, Lagaly G (2001) Baseline studies of the clay minerals society source clays: layer-charge determination and characteristics of those minerals containing 2:1 layers. Clay Clay Miner 49:393-397
Mifsud A, Rautureau M, Fornes V (1978) Etude de l'eau dans la palygorskite à l'aide des analyses thermiques. Clay Miner $13: 367-374$

Murray HH (2000) Traditional and new applications for kaolin, smectite, and palygorskite: a general overview. Appl Clay Sci 17:207-221

Pevear DR, Mumpton FA (1989) Quantitative mineral analysis of clays (1989) The Clay Minerals Society. Evergreen. Colorado. p 171

Polette-Niewold LA, Manciu FS, Torres B, JrM Alvarado, Chianelli RR (2007) Organic/inorganic complex pigments: ancient colors maya blue. J Inorg Biochem 101:1958-1973

Rautureau M, Caillere S, Hénin S (2004) Les argiles. Ed Septima, Paris

Rhouta B, Kaddami H, Elbarqy J, Amjoud M, Daoudi L, Maury F, Senocq F, Maazouz A, Gerard JF (2008) Elucidating the crystalchemistry of Jbel Rhassoul stevensite (Morocco) by advanced analytical techniques. Clay Miner 43:393-404

Rouquerol F, Luciani L, Llewellyn P, Denoyel R, Rouquerol J (2003) Texture des matériaux pulvérulents ou poreux. In Techniques de l'Ingénieur, traité Analyse et Caractérisation P1050:1-24

Ruiz-Hitzky E (2001) Molecular access to intracrystalline tunnels of sepiolite. J Mater Chem 11:86-91

Serna C, Van Scoyoc GE, Ahlrichs JL (1977) Hydroxyl groups and water in palygorskite. Am Mineral 62:784-792

Shariatmadari H (1998) Interactions of phosphates and selected organic molecules with palygorskite and sepiolite. PhD Thesis. University of Saskatchewan. p 213

Sing KSW, Everett DH, Haul RAW, Moscou L, Pierotti R, Rouquerol J, Siemienwska T (1985) Reporting physisorption data for gas/ solid systems with special reference to the determination of surface area and porosity. Pure Appl Chem 57:603-619

Su D, Wang C, Cai S, Mu C, Li D, Lin W (2012) Influence of palygorskite on the structure and thermal stability of collagen. Appl Clay Sci 62-63:41-46

Suárez M, García-Romero E (2006) FTIR spectroscopic study of palygorskite: influence of the composition of the octahedral sheet. Appl Clay Sci 31:154-163

Thorez J (1976) Practical identification of clay minerals. In: Lelotte G, Dison (ed) A handbook for teachers and students in clay mineralogy, Belgium

Van Olphen H (1966) Maya blue: a clay mineral-organic pigment? Science 154:645-646

Wang M, Liao L, Zhang X, Li Z (2012) Adsorption of low concentration humic acid from water by palygorskite. Appl Clay Sci 67-68:164-168

Woessner DE (1989) Characterization of clay minerals by ${ }^{27} \mathrm{Al}$ nuclear magnetic resonance spectroscopy. Am Mineral 74:203-215

Yacamán MJ, Rendon J, Arenas J, Puche MCS (1996) Maya blue paint: an ancient nanostructured material. Science 273:223-225

Zhao D, Zhou J, Liu N (2006) Characterization of the structure and catalytic activity of copper modified palygorskite/TiO ${ }_{2}\left(\mathrm{Cu}^{2+}\right.$ PG/TiO 2 ) catalysts. Mat Sci Eng A-Struct 431:256-262 